THE MANUFACTURE OF GONGS IN SEMARANG

(Edw. Jacobson and J. H. van Hasselt)

Translated and with an Introduction by Andrew Toth

\title{
Introduction
}

This is a translation of De Gong-Fabricatie te Semarang by Edw. Jacobson and J. H. van Hasselt, which was published in Leiden in 1907 by the Rijksmuseum voor Volkenkunde through E. J. Brill (Series II No. 15). Although written more than sixty years ago, this work still remains the definitive study of the processes and technology used in the manufacture of gongs by the Javanese.

Various authorities have proposed different places and times for the origin, as well as different courses of evolution, of the gong: northwest Further India (southwest of China); ${ }^{1}$ the Near East, eighth century B.C., developing from the knobless form (disque sonore); ${ }^{2}$ and Indonesia (Java), fourth century B.C., evolving from bronze drums from the mainland and ultimately the Dong-Son culture. ${ }^{3}$ However, in the end it has been the Javanese who have refined the art of forging gongs, elevating it to its highest level of complexity and producing instruments with supreme beauty of sound and form, as exemplified especially in the gamelans to be found in the courts of Central Java. The fact that this work is a careful study of the processes and terminology of this trade, as well as the current rarity of the original edition, are the reasons for this translation (the original text did include a German translation by J. D. E. Schme1tz).

A11 of the original plates, figures, footnotes, and the master list of terms in Javanese are included in this translation. However, in addition to giving more complete information for the original bibliographic entries, new footnotes (marked TN) have been inserted in order to clarify or supplement various points in the text with more recent bibliographic references to tuning, voicing, history, and mythology. Omitted are Schme1tz's translator's preface and the general index.

Author's Foreword

The instructive and research-stimulating work of $\mathrm{Mr}$. G. P. Rouffaer, De voornaamste industrieën der inlandsche bevolking van Java en

1. TN: See Heinrich Simbriger, "Gong und Gongspiele," Internationales Archiv für Ethnographie (Leiden: E. J. Bril1, 1939), XXXVI, pp. 1-180.

2. TN: See Jaap Kunst, Music in Java; its History, its Theory and its Technique (3rd ed.; The Hague: Nijhoff, 1973), I, pp. 142-48. Also by the same author, "A Hypothesis about the Origin of the Gong," Ethnos, XII (1947), pp. $79 \mathrm{ff}$. and 147.

3. TN: See Mantle Hood, "Music of the Roaring Sea" (2 vols.; in preparation). Also by the same author, "The Effect of Medieval Technology on Musical Style in the Orient," Selected Reports, I, No. 3 (1970), pp. 148-70. 
Madoera (The Hague: Nijhoff, 1904), aroused our interest in a branch of industry that is a true Javanese form, the manufacture of gongs in Semarang. Although the sound of this instrument has been heard frequently, until now it has attracted little attention on the part of ethnographers. The literature concerning this industry is extremely limited, and we were not able to find practically any detailed description.

On page 112 of the work mentioned above, Rouffaer reaches the conclusion that ". . . in terms of copper alloys, serious consideration must first be given to the forging of gongs, since this trade represents ün old, yet still vital specialty of Java. . . ."

This was the reason that we decided to undertake a thorough investigation of the manufacture of gongs in Semarang. We saw and heard there so much worthy of remark that we believe valuable contributions can be made to the knowledge of this important trade through publishing our observations.

Our research is by no means complete; on the contrary, there is much that requires more thorough study, as for example the technique of tuning the gongs.

For the sake of comparison it would also be desirable to investigate the manufacture of forged gongs in Solo, Pagongan, and perhaps elsewhere. What remarks we have made about this trade in places other than Semarang are not the result of our own research, but rather based on the explanations given by the smiths in Semarang. It is likewise not yet certain how great a sales volume there is for the finished gongs. Other instruments offer still another field of study; it will please us if we have prompted further clarification of ambiguous points.

We owe our gratitude to many who gave advice and assistance for this publication: among others, Miss M. Tonnet, Professor A. L. van Hasse1t, and Dr. J. D. E. Schme1tz. To Dr. J. H. Cunning we are obliged for the correct orthography of the Javanese words; it should be emphasized here that most of them are technical terms, used in practice by only the gongsmiths.

Thanks are also due to Mr. O. Hisgen, photographer in Semarang, who completed and illustrated our description with his excellent photographs.

A collection of the objects shown in these plates is to be found in the 's Rijks Ethnographisch Museum in Leiden (series 1564, in 1906), and a similar one in the Museum voor Land-en-Volkenkunde en Maritiem Museum Prins Hendrik in Rotterdam. 


\section{THE MANUFACTURE OF GONGS IN SEMARANG}

Since early times Semarang has been famous in the Indian archipe1ago for its gongs, in Java as well as the outer islands. The kind made there is generally recognized among East Indies musicians as the best.

In Semarang the workshops of the gongmakers are restricted to the kampong Gendingan, 4 where seven Javanese masters practice this trade at the present time (early 1906).

The gongmakers (tukang gending) ${ }^{5}$ are, according to Javanese conception, special people. The following is a list of the names of the present representatives of this trade, given in their own order of rank:

Pak Ladina
Pak Alia
Hama
Barum
Basirun
Kastam
Simun

The first two are not really smiths but rather proprietors of the workshops in which experienced workers are employed to make gongs, which are then sold through them.

Moreover, the owners also buy the raw materials and important tools for the work. The judging of the test-castings comes under their supervision, while in general the management of the entire business lies in their hands.

In the gongsmithy (besalen), not only are the true "gongs" of the gamelan made, for which orders are placed fairly seldom nowadays; all of the other known gong- and percussion-instruments are made there as we 11 .

The main part of this trade, however, is comprised of the production of the bende and the kempul, that is, those gongs whose weights are respectively a maximum of ten or eighteen kati. ${ }^{6}$ Gong, the true

4. Gending means "musical piece"; this term is applied figuratively to the gamelan, the prominent Javanese orchestra on which musical compositions are performed, and furthermore to the various individual metal percussion instruments that make up the orchestra. Thus kampong Gendingan $=$ kampong (town subdistrict) where the metal instruments of the gamelan are made.

5. The Javanese apply this name to the owners of gongsmithies. A true term in the Javanese language does not appear to exist; perhaps such a name is to be found in use in Solo.

6. TN: Kati is an indigenous unit of mass-weight, variously cited as being equal to 617-625 grams (about 1.4 pounds). Pikul (from Malay "to bear on one's shoulders," that is, "a man's load," is equal to 61.76 kilograms (136.16 pounds) in Indone- 
name of gongs over eighteen kati, is frequently applied to all of them as a generic name (as we do here). From this it is apparent that the kempul and bende can sometimes be the same weight.

Aside from weight, the Javanese themselves make further distinctions according to size. It is thus possible that a very thinly hammered-out and consequently large kempul is lighter than a small but less hammered-out bende. The manufacture of the metal keys (wizah) for the Javanese percussion instruments is of very little importance in Semarang; according to the gongmakers this is due to competition given them in this respect by similar workshops in Solo.

A gongsmithy is an open shed, usually roofed with tiles or sheetiron, which gives a highly primitive impression to the European.' It contains two or more hearths, one of which is sometimes of much greater size than the others. This is for making large pieces of thirty-five kati or more.

The making of a gong is done by a group of workers. This workgang consists, in the first place, of true gongsmiths, six at the most.

The leader of these six is called the panji, the master gongsmith. ${ }^{7}$ Following him in their order of technical know-how are:

1) the malu ngarep,

2) the malu nempong,

3) the malu ngalap,

4) the malu nulup, and

5) the nulup, the helper who is used by the smith only if a large gong is being made. In the smithy there are also one of the bellows operators, called ngaroni, and an indefinite number of student helpers (rewang), whose task is the procurement of water and charcoal and the performance of other similar chores.

The forging of a gong (pande gong) requires long practice and close cooperation among the workers; the apprentices are trained in smithing from their youth, and the forging is done preferably, and usually as a rule, by integral groups. A result of this is the remarkable fact that if one member of the group is absent due to sickness, and so forth, usually the entire group stops the work.

The following floorplan (see Figure 1) gives an idea of the workshop in which such a group practices the trade. It should be remarked that the melting and alloying of the metal is done here.

At $a$ is the hearth (prapen), actually a shallow, round pit filled with charcoal, which deepens in its crater-like center. A subterranean channel $b$ (dungu) connects the center of the pit with another shallow rectangular pit $d$, and is closed by a stone called punuk, $p$.

sia. Thus there are approximately 100 kati per pikul. Another standard of weight used by smiths in Bali is the string of képéng (Chinese coins).

7. TN: When forging a large gong, the smiths adopt names taken from the autochthonous Panji stories as protection from dangerously powerful forces involved especially with metal. See Kunst, Music in Java, I, pp. 137-39; W. H. Rassers, "Inleiding tot een bestudeering van de Javaansche kris," Mededeelingen der Konink1ijk Akademie van Wetenschappen, I, No. 8 (1938). 
The dungu conducts the airsupply for the fire. A11 of the forging areas can be indicated collectively by the word dungu; that is, one says that a gongmaker has two or more dungu, as we would say a smith has two or more forges.

The punuk is pierced by one or two tubes, called suling (actually "flutes"), indicated by $c$, to which the previously mentioned bellows are later attached.

In the smithy there are three stone anvils whose bottoms are set into the ground. They are the watu tandes (h), the watu mindan (e), and the watu plarapan $(g)$.

At $^{i}$ is a small cement waterbasin (kobokan) set into the ground, partly closed by a small board, and in this lies a brush (kobyok) of bundled ricestalks. $K$ indicates the position of a wider, larger round water basin (plandan) set and cemented into the ground, in which the finished pieces are cooled. $F$ is the position of a shallow rectangular pit over which a board lies, as the seat of the panji.

At $l, m, n$, and $o$ in each case are two parallel boards (telundak) set almost flush into the ground. On these the smiths lay their hammers in order to prevent their contact with the dirt floor.

Plate I should be referred to for a better understanding of the floor plan. One of the forges in each smithy is usually designed for making large gongs (over twenty kati). This forge differs from the others not only by its greater size, but also by the fact that the airchannel $c$ has not one but two suling; also, there is usually in the rear another miniature hearth with an airchannel, which we will explain shortly.

The raw materials from which the gong and all other Javanese keyand gong-instruments are made are: copper (tembaga) of high purity $(98-99 \%)$, and tin (timah rejasa).

The copper is obtained through European traders and comes from Japan or Australia. The Australian type is in the form of blocks (tembaga bolu), and the Japanese kind that of plates (tembaga sagu). The gongsmiths prefer the Japanese variety, which is electrolytic copper, because of its great purity and malleability.

In earlier times the Japanese copper came in the form of thin sticks (tembaga lantakan). This kind has not been imported for many years.

The tin comes from the auctions in Batavia (Banka-tin). Both raw materials are presently very high in price, so that the gongmakers pay the Chinese middlemen 62-63 guilders per pikul of copper, and 120 guilders per pikul of tin.

Some of the more enterprising smiths buy their copper directly from European merchants. Because the high price of copper would eliminate the profits of the smithy owners, old copper articles (dandang, dalung, and so forth) are now frequently melted down and mixed with block copper in the proportion of three to seven. This material is also used under usual circumstances, in small quantities. This type of old, used copper (tembaga rosokan) costs about 45 guilders per pikul. The making of a gong can be divided into the following steps: 
the casting,

the forging,

the finishing (filing, turning and polishing), and

the voicing and tuning.

The Casting

The bronze alloy used for making metal instruments is called gangs a and consists of ten parts copper to three parts tin. ${ }^{8}$

According to the present gongsmith's knowledge of his colleagues in Solo, Banjarnegara and elsewhere, where wilah and bonang are made, the art of preparing gangsa is no longer known, and o1d broken instruments are instead melted down.

The quantity of bronze required for an entire week is usually prepared on Friday afternoon. Five to six pikul per day can be produced from one forge.

This happens in the following way: a large crucible (kowi besotan) is placed in the charcoal in the forge, and is itself partially filled with charcoal. The making of this crucible, as well as the other smaller crucibles that are used, is done by special workers (tukang kowi); two of these currently live in kampong Gendingan, namely Pak Drachman and Abdoel Gapar.

A mixture of red clay (tempung abang) from the hills in the vicinity of Semarang, and burnt brambut or merambut, husks and cut stalks of padi (rice), makes up the raw material for the freehand-formed crucible, which is fired after having dried out in the air.

After the crucible has been set into the charcoal and the fire in the forge kindled, the copper blocks, mixed with charcoal, are piled up in the crucible, and the whole covered with additional charcoal.

The charcoal (areng), which is used by the smith for melting down as well as for heating pieces, is made exclusively from jati wood (tectona grandis L.); areng from kesambi wood (schleichera trijuga WILLD.), which would seem to be the best, produces too much heat, according to the workers, by which the pieces would be unevenly heated and could be damaged by oxidation. For the melting process, a special bellows system over the fire rather than the subterranean air channel is used to fan the areng fire (see Plate II).

This consists of a suling, a thick bamboo tube (bambu petung = Bambusa nigro-ciliata BUSE) with bored-out septa (now an iron tube is frequently used instead), which slopes over the forge, the lower end in the adjacent pit (indicated by $d$ in the floorplan). It is pivoted in its middle on a crosspole, fixed in the appropriate position with a pair of weighted boards.

On the end over the forge is a fired tube, made of a mixture of black clay (lempung) and sand (pasir), caulked at the joint with moist clay. This tube is called congkzok, and has at the end over the forge another piece perpendicular to its running length, which is again made

8. TN: See J. G. Huyser, "Oud-Javaansche koperlegeeringen," Cultureel Indië, I (1939), pp. 227ff., 257ff., $292 \mathrm{ff}$. 
of two parts, namely a nozzle (telale, actually "snout") and a spherical section (popokan), which joins together the congklok and telale. The telale is positioned in the charcoal pile so that it opens directly over the crucible. At the other end of the bamboo tube is attached a sack made of goatskins sewn together, with the hair not removed.

The upper side of the sack has a wide slit that serves as the air intake. Thịs extremely primitive bellows is called lamus, but it requires a certain amount of dexterity to be able to work it. The helper charged with this work, the ngaroni, sits on the ground, holding the lamus between his knees with both hands, while he holds fast the extreme end of the slit with his right elbow resting on his thigh.

The sack is now stretched open and simultaneously lifted, so that it is filled with air entering through the slit; then the sack is compressed and the slit held shut with the hands and right forearm. The air streams through the suling and issues forth through the telale fixed to the other end. This fanning of the fire is called di lamus; it is continued, with the addition of new charcoal to the fire, until the copper has melted down in the crucible.

The melting process is called besot. After the copper has completely become liquid (wistuwa = "already old" = "done"), the necessary quantity of tin is added. Using both iron rods (penyukat gogol and penyukat pengiwa), the workers mix well (ngudeg) the metals and remove the slag (krawa).

During the melting there is a great loss (suda) due to oxidation and mixing with slag. Through this first and later second melting, about $25 \%$ in total of the raw material is lost.

The small metal slugs (kenyi) that go off with the slag are sifted from the charcoal by the helpers (rewang), and are sold back to the smith for 50 cents per kati. Two kinds of slag are distinguished: first, krawa tembaga from the first melting, that is, copper slag, and secondly krawa gangsa from the second melting, which contains mostly tin oxides. In the jargon of the gongsmiths, these byproducts are more specifically named krawa besotan and krawa wedel, respectively.

The alloy is assayed by means of making small test-castings. This process will be described later in the making of the lakar.

The liquid bronze is poured (nyidugi) into cavities (Zeleran) simply dug in the smithy floor, with iron ladles fastened to the ends of long wooden handles (batok wesi). The large flat plates thus formed, also called leleran, weigh about one pikul and must cool in the air so that they become brittle and can be broken into pieces. This fragmenting is done with an iron hammer, geblog; the head is heavy, square at one end, round on the other and fastened on an extremely short handle.

Before the actual production of the gong is begun, the bronze alloy must be again melted down. The required amount for a given gong is weighed out from the quantity of broken leleran, figuring in another expected loss as slag in this second melt.

The required time for this event can be approximated from the fact that the melting of about 35 kati lasts about an hour. 
The melting of the broken leleran follows the same procedure as for the original alloying. This second process is called nglebur. The corresponding crucible, kowi leburan, is much smaller than the first one used, and has a spout as well.

While the pourer is busy at the forge, one of the helpers is preparing the mold, penyingan. These molds, which occur in different sizes according to the size of the gong which one wishes to make, are made of a mixture of gray clay (Lumpur), sand (pasir), fine gravel (krikil), and unburned brambut mentah. The molds have the shape of extremely thick disks, which have only a slight depression on top. Into this shallow cavity is poured the melted alloy, which upon cooling assumes the protoform of the gong, namely a flat metal disk slightly convex on one side. Before each casting the mold must be first prepared in the proper manner, in which the holes and cracks from earlier use are filled with a mixture of loam and fine charcoal. The depression which the metal will occupy is then given further treatment; its entire surface is coated with a mixture of loam and sweepings from the roof of the smithy, consisting of soot and charcoal ash.

After this treatment, called ndaliti, the mold is dried in the fire and carefully cleaned.

Meanwhile, the metal has melted in the crucible and is ready to be tested, di gecak. Two test-castings are needed for judging the quality of the alloy.

The tools used for these are: a small crucible about ten centimeters high with a spout, the kowi cucuk (cucuk = "spout"), and the watu jujutan, a small flat stone with a shallow depression.

The panji grasps the kowi cucuk with tongs (supit) and with this smaller crucible scoops out some of the liquid metal from the kowi leburan; a portion of this is poured into a small round depression made in a pile of sand, and the rest into the depression in the watu jujutan, after this has been coated with coconut oil.

When the sandcasting has set, it is further cooled by one of the helpers who rolls it back and forth in a small pile of damp charcoal and sand. The small metal plate thus formed is called gecakan. This is now fragmented by pounding with a geblog. Slow cooling is applied here, as for the leleran, in order to produce brittleness and to facilitate the fragmenting.

The judging of the test-castings requires great experience and consequently is done by the panji himself and the malu ngarep. If the cross section of the gecakan at the break is very rough and reddish, then the alloy contains too much copper; this error is corrected by adding tin fragments to the liquid metal. If the break is smooth and shiny, then too much tin was used; such a mixture is called wareg ("saturated"). In this case, either small sticks of copper are added or the alloy is heated a while longer so that part of the tin oxidizes and is carried off with the slag.

When the second test-casting is made in the watu jujutan, the heat of the liquid metal ignites the coconut oil; at the same time brambut is strewn upon the surface, thus also burning. The aim is to retard cooling. 
In contrast to the rough surface of the more quickly cooled gecakan, the metal piece (jujutan) formed in the watu jujutan remains completely smooth because of the slow cooling.

As soon as the jujutan has sufficiently set, still a glowing dark red color, one end of it is pounded out into a thin tongue and bent over to determine whether the metal will crack or break. If this does happen, it is proof that the copper used was of insufficient purity. The actual gongcasting is not made until the tests (gecakan and jujutan) have met the established requirements.

The gecakan and jujutan belong as waste to the helpers, who sell back this bronze to the smithy owners for 50 cents per kati.

If the testing shows that the alloy is of the desired quality, then the actual casting may be done. The melting crucible is dug out and the slag struck out with a stirring rod. Two helpers then grasp the crucible with tongs (supit), lift it out of the pit and place it in a charcoal pile near the mold, into which coconut oil has been poured in order to prevent the liquid alloy from quickly setting (kraket).

The supit is a pair of iron tongs whose crescent-shaped backs are widely bent out and meet only at the flattened-out mouth.

Holding a pair of tongs in each hand, the panji now pours the contents of the crucible into the mold. This is called di sok (see Plate I I .

During the pouring, the face of the panji is protected from the scorching heat of the melted bronze by a rattan screen (aling-aling) with a long handle, which is held by one of the helpers between the panji and the crucible. The panji observes the progress of the work through the cracks in this screen.

As with the casting of the jujutan, the melted metal is now strewn with brambut, which burns along with the oil. The residue floats to the top with the slag, and is skimmed off with the iron rod; new brambut is subsequent1y added.

If the slag and air bubbles have risen to the surface, this mass is allowed to stiffen somewhat in the form, so that it may be more easily removed.

The round flat plate that is cast, only a few centimeters thick in its middle, is allowed to cool to room temperature. It is called lakar and is the first stage in the progressive forging of the final gong shape. The crucible is washed out with water immediately after emptying and warmed in charcoal embers; otherwise it would cool too quickly at room temperature, and the resulting cracks would allow the metal to ooze out during melting.

The lakar is always cast in the afternoon, and the actual forging or pounding begins the following morning.

\section{The Forging}

The pounding (pande) is done with iron and wooden hammers of different shapes and sizes, according to their use in forming the different 
parts of the gong. Each of these hammers has its own name.

$\frac{\text { Iron Hammers (see Plates VI and VII) }}{\text { geblog }}$
palu
palu alang
cocor mindan
penunggalan

Wooden Hammers

perbahan

papak

prapeh

munjulan

Zaga

mason

In order for the reader to understand more fully the different stages in the forging and shaping of a gong, we first give here an exact description of the various parts which the Javanese gongmaker differentiates in a gong.

Figure 2 shows a side view of a gong. The knob or boss $a$, which the Javanese layman calls pencu, is known to the gongmaker as endas ("head"). 9

The projecting edge of the boss, $b$, is named tikel; the flat part e, rai; the ledge $d$, pasu; the bent part $e$, rejeb; and the rim $f$, dudu. The sidewall, as a whole called kaki ("foot"), 10 is further differentiated into bau $(g)$ and the bottom edge, lambe $(h)$. The opening or the interior itself of the gong is called lolohan.li

The anvils on which the gong is pounded are made exclusively from stone, a very hard and dense kind of gray volcanic rock, which the gongmaker himself procures from gorges at the foot of the volcano Merapi at the desa (village) Kenteng. Suitable stone can probably be found elsewhere, but tradition has it that in earlier times the Susuhunan of Solo, Paku Buwana II Bagus, commanded the gongmakers to obtain stone for anvils from no place other than Merapi, and since then all have followed this prescription.

The stone is selected according to uniform density and color; if the stone shows a pinkish-gray color (ules wungu) at a crack, this is a sign to the good. Such stones can be used about twelve years, according to the workers. The average weight of an anvil is about 10-15 pikul. Shipping such a stone to Semarang costs about thirty guilders.

9. See A. M. K. de Does, "Toestand de Nijverheid in de afdeeling Bandjarnegara," Tijdschrift voor Indische Taal-, Land-, en Volkenkunde (TKI), XXXVI (1893), pp. 98-107 and Plate IX. According to de Does, the term for the boss that is used by the gongmakers in Banjarnegara is pencu; in Semarang this is decidedly not the case.

10. Kaki is a Malay word commonly used at present by the gongmakers in Semarang. However, they also use the Javanese term bau as well to indicate the entire sidewall.

11. TN: For other terms used for the parts of the gong, see Kunst, Music in Java, I, p. 141 . 
Frequently a stone breaks during normal use or must be declared unsuitable for other reasons.

To be used as anvils, the stones must be hewn into various shapes. The flat working surfaces are hewn out (nacahi) with an iron hammer (penacah), while final polishing is done with a particular kind of stone, watu $2 a s$. According to the workers, this is imported from Pontianak. It is fastened on the lower end of a length of bamboo, which is hung vertically over the anvil surface between the posts of the smithy by means of two ropes. This is swung back and forth, so that the stone polishes the anvil with each pass. This process is called ngansapi and is usually repeated every three months, in order to correct damage of the working surface of the anvil. The watu tandes, the most frequently used anvil (indicated by $h$ in Figure 1 ), is set into the ground so that the buried underside is level, while the fairly square, upper surface lies rather obliquely and slopes upward.

The square, flat, polished upper surface of the second anvil set in the ground, the watu plarapan or watu lodok (Figure 1, g), is exact1y level with the ground.

Another anvil used is the watu mindan (Figure $1, e$ ), a square stone set in the ground on the edge of the pit (Figure 1, d) so that its top lies flush with the ground and the flat, polished side flush with the sidewall of the pit.

The use of stone anvils is due to many reasons. Tradition and age-old use play a great role here. The gongmakers would hardly be able to repair an iron anvil which had been damaged through long use, while such refinishing is easier for a stone anvil. However, the real reason seems to be that on an iron anvil the hammers would also rebound with much too great force, due to the far greater elasticity of iron compared to stone. In this situation where the three or five smiths must stand close to each other on one side of the anvil, because of the shape of the workpiece, this rebounding of the hammers would be dangerous for them.

Gongs weighing up to twenty kati are forged in the smaller pit, while heavier pieces, which require more heat, are made in the larger pit, whose dungu is serviced by two bellows. These bellows are operated by two helpers, the aforementioned nulup and ngaroni.

When the forging is to be started, one of the helpers places a lakar in the previously started fire. The panji, who sits on a board lying over the pit during the entire process of forging, grasps the lakar with two iron tongs with wooden handles (see Plate I).

The longer of these tongs (penyukat gogol) is held in the right hand, the shorter one (penyukat pengiwa) in the left hand. Their size varies according to the dimensions of the workpiece. Formerly very short rods (penyukat lakon) were primarily used, but these are no longer employed.

The end of the penyukat is bent like a hook, while the end held by the panji is fixed in a wooden handle (garan) by means of an iron ring, karah. The panji handles the workpiece with these tools so skilifully that he can lift it, turn it over, or rotate it; because of this it remains in constant motion and receives an equal distribution of heat. 
Figure 3 shows how an already partly forged gong is held by means of the penyukat, while it is lying in the pit.

A wooden board called anggel, placed near the pit, is used as a prop for the penyukat during this procedure (see Figure 1,a).

The lakar is heated to a glowing, dark red color in this manner of continuous motion. 12

Determining the proper length of time of heating requires great exactitude, since the piece would break during pounding if it were heated too much or too little. For this reason the smithy is intentionally kept extremely dark, since the panji could not correctly judge the color temperature with too much extraneous light.

The glowing lakar is now taken from the fire by one of the helpers with an iron rod, and inclined on its edge on the watu tandes. The panji holds the plate with two pairs of tongs, while the helper holds an iron rod, whose end is hooked, behind the lakar as a support (see Figure 4).

The first smith (malu ngarep) then strongly pounds on the outermost portion of the face of the lakar with the geblog. For a large gong two smiths must work the piece, one with a geblog and the other with a palu. After each hammerblow the panji rotates the lakar a bit with the tongs, so that the entire edge is equally pounded. This is called nesek. The piece is then laid in the fire by the helper and again heated.

By far the most frequently used tool in gongmaking is the palu, an iron hammer weighing thirteen to fourteen kati, with an extremely long wooden handle. The handle is set in the rear rectangular part of the head, while the remaining portion, about thirty centimeters long, is cylindrical and gradually tapers to the striking end, which is capped with steel.

During the described process of pounding called nesek, a coating of moist loam is laid down by a helper on the half of the watu tandes nearest the forging pit. This base, called luluh, serves to support the workpiece in the desired position for pounding. The part of the gong which is pounded, however, always lies directly on the stone. The luluh consequently does not parry the hammerblows but is instead on1y a supporting substratum.

During the various different treatments of the changing shape of the piece on the watu tandes, it must lie now more, now less obliquely on the anvil. This is done by adding or removing loam from the luluh. For the same reason, strips of gedebog pisang (banana tree stalk) are laid on the luluh; this facilitates the rotation of the workpiece on the underlayer of clay.

The luluh is continually moistened with water from the kobokan, with the brush made of padi-stalks.

According to the local smiths, their colleagues in Solo use sand instead of loam for the luluh, and this is said to be less suitable.

12. It is not heated to the melting point, as stated by de Does, "Toestand der Nijverheid." 
When the actual pounding ( $d i$ pazu) begins, the glowing lakar is laid flat on the watu tandes, and the smiths stand next to each other on one side of the anvil with their hammers (palu).

The malu ngarep, who stands next to the panji, gives the first hammerblow to the middle of the plate, and after him follow respectively the malu nulup, and the nulup; then they reverse the order, so that the malu ngarep gives the last hammerblow. During this pounding the smiths set their left foot forward, with the exception of the last to the right in this order, who sets forward his right foot (see Plate I I I).

The hammerblows follow very quickly after one another; yet the panji, who holds the workpiece by its edge with two pairs of tongs, is able to give it a small (clockwise) turn between blows, so that the area covered by each consecutive strike partially overlaps the previous one, like rooftiles, so to speak. At the same time, the smiths place their hammerblows beginning in the middle and progressing outward in a spiral to the outer edge of the workpiece.13

This pounding lasts for only a short period each time (about half a minute), and since the piece has then already cooled too much, it must be reheated, which also takes about half a minute each time, or somewhat longer for larger gongs. This reheating of the piece until it glows (di bangi, from abang = "red," "to make red") is continually repeated, so that a tenkati gong is taken out of the fire a good 150 times, for example, and larger pieces even more often.

Places that are too thick are marked (guris) with chalk, which does not disappear in the fire. After the next heating the smiths then take note of which places they must pound more strongly.

Besides the panji, three other smiths are necessary for a gong of 5 kati, four for one of 10-18 kati, and five for gongs above that weight.

For the infrequent gong of 45-50 kati, two panji are employed; one handles the piece in the pit, the other on the anvils. For making such a heavy gong still another helper is called, the ngalap (not malu ngalap), whose work consists of carrying the piece between the fire and the anvil.

As the lakar is progressively worked it becomes more concave (kuwung) and begins to assume the shape of a bow1 and then gradually that of a gong.

After the piece has been shaped this far with the palu, the still somewhat crude form is worked in the following way, for which it must be reheated each time.

First of all, irregularities in thickness are hammered out flat on the watu tandes with the papak. This is a thick cylindrical wooden hammer which is a good half meter in length, with a handle attached to the middle. For a large gong the perbahan is used, which is nothing more than the papak on a larger scale.

13. TN: For a sound recording of the forging with hammers, see "Chants et Danses d'Indonesie," Chant du Monde LDY 4179, 2 s. 7" 33 1/3 rpm. Recorded by Bernard IJzerdraat, notes by Etiennette Benichou. Side B, band 2 . 
Next the boss of the gong is partly hammered out (called ngejor) with the usual palu by a group of three smiths. For further working of the boss with the palu, the piece is laid halfway on the watu plarapan, and the boss is supported in a small depression (lodok) in a pile of loam on the ground next to the anvil. For hammering out the boss the smiths pound directly in the center; because of their great skill it is unnecessary for them to take the precautions which de Does mentions of the gongsmiths in Banjarnegara.14 During the stages of handling on the watu plarapan where exactness is required, the interior of the gong is illuminated (nyoloki) with a length of burning bamboo.

The boss is then given the correct final shape with the munjulan. This is a conical wooden hammer which is a good half meter in length, whose handle is attached near the thickest end of the head. The other, rounded striking end is covered with a brass cap.

Next attended to is the edge or sidewall (kaki, see Figure 2, g). From previous pounding with the palu it is inclined too far towards the inside of the gong and is otherwise unevenly bent. The sidewall is correctly shaped ( $d i$ minda) with the prapeh and the cocor mindan.

The prapeh is a thick, very short, cylindrical wooden hammer with a long handle fastened in the middle of the head. The rear flat end of the cylinder is straight, while the striking face is obliquely angled in towards the bottom.

For minda the anvil used is the watu mindan (indicated by $e$ in the floorplan in Figure 1), which is set into the wall of the pit $d$. The cocor mindan is a short rectangular iron hammer with a very long wooden handle. The somewhat broadened striking end is similarly angled in towards the handle.

Two lengths of wood are now laid in the pit $d$ parallel near each other with one end of each against the watu mindan. Over these sticks are placed strips of gedebog (banana trunk), and on top of that the glowing gong. The underlayer of soft banana trunk facilitates the turning of the gong and positions it more solidly, so that the projecting boss does not touch the ground. The sidewall of the gong is hammered flat from inside with the prapeh against the side of the watu mindan (see Figure 5).

A process of flattening on the watu plarapan occurs again now, first with the papak and then with the Zaga, with which the rim common to the face and sidewall of the gong, called dudu (Figure $2, f$ ), is equally rounded.

Next the rejeb (Figure 2,e) is worked from inside with a special technique called ngacak, for which the laga is used in a peculiar combination of pounding and rubbing. The laga is a long, heavy wooden hammer about a half meter long, with a wooden handle fastened in the middle of the head. The latter is more or less in the shape of an inverted boat, whose ends are cut off obliquely and somewhat rounded (see P1ate VII, 9).

The next step in the work is the clarification of the ledge pasu (Figure 2, d). This is pounded out from the inside with the sharp end

14. See de Does, "Toestand der Nijverheid," pp. $94 \mathrm{ff}$. 
of the wooden mason ( $d i$ masoni). The cylindrical head of this hammer is about a half meter long with sharply cut-off ends; the handle is fastened in the middle. 15

Before the glowing-hot gong is now cooled in water, an iron hoop (blengker) of the same circumference as desired for the gong is taken, and three strips of banana-trunk rind are tied to it as handles. The hoop is now laid around the sidewall (kaki) of the gong, whereupon the gedebog strips are burned off by its heat. Then the gong together with the hoop is plunged into the water basin (Figure $1, k$ ). The hoop prevents the gong from incorrectly expanding (penjol) because of the sudden cooling.

By this cooling procedure, called ngelem, the metal is hardened and made elastic. If it were allowed to cool slowly in the air, it would crack and break during use.

If it is apparent that the gong is not completely even around its bottom edge, it is placed in the pit at an angle against the watumindan, and over it is laid a wooden pole whose free end is supported (see Figure $6, a)$. Two other sticks $(b$ and $c)$, which cross each other above the pole $a$, are inserted into the cavity of the gong and pressed down on the other end by one of the helpers, whereby leverage is applied to the edge of the gong. At the same time the panji removes the unevenness from the edge with an iron hammer, the cocor seletan. This work is called bentang.

The cocor seletan is a very small rectangular iron hammer with a short wooden handle. The striking end of the head is cut off somewhat ob1ique1y.

In order to give the face of the gong the correct curvature, an apparatus is used as shown in Plate IV; it is called metakan, while the procedure itself is known as metak. It consists of a short wooden block partially sunk into the ground, and a horizontal crossbeam about $2 \frac{1}{2}$ meters long which is inserted in a square hole in one side of the block. The beam has enough play in this hole to be rocked up and down at its free end. The gong is laid under it on a board. A small conical piece of wood called umbul is now placed vertically on the part of the gong called the rejeb, and using the crossbeam as a lever, the worker exerts pressure on this cone and through it on the rejeb, thereby holding the latter in the desired curvature.

According to the size of the gong, a longer (umbul dawa) or shorter cone (umbul cendak) is required. The shape is formed permanently by pounding with an iron hammer, the penunggalan, on the metal near the umbul; otherwise the metal would spring back as soon as the pressure was released.

The penunggalan is a small palu weighing $1 \frac{1}{2}$ kati with a short handle. The shaping of the rejeb is called di kirih-ake.

Now the gong is turned over after removing the board in order to correct any damage done to the boss. In the same way as described

15. The pasu of the bonang, which has a very high, prominent rim, is formed by pounding with the iron palu alang, a small hammer with a very long, rounded striking end. 
above for the exterior, the inside of the gong is treated to give the proper shape to the rai and pasu; this is called njuluk.

With this the actual forging is finished. However, several less important but appropriate remarks are necessary here. The reheating of the workpiece must be done carefully and slowly; otherwise it might crack with a loud report. It is well known that large castings made from copper alloys are very sensitive to cold drafts during the cooling period.

The face of the panji is protected from the scorching heat of a large gong during reheating as well as the initial casting by a latticed bamboo shield (aling-aling). The hands are protected when holding the tongs by glove-like, conical pieces of wickerwork (rattan) called contong. A smith also frequently protects the foot set forward during pounding by wrapping gedebog-pisang and guni around it.

These precautionary measures are only necessary, however, for gongs weighing more than 35 kati.

For a particular type of gong, a groove is hammered in around the pencu, as indicated schematically in Figure 7 with $a$. This is done with the penunggalan, and the groove is called widengan. Its function is the production of a fuller tone, especially in smaller gongs, and these as such are in demand principally in solo.

According to the gongmakers, this feature was adopted during the Majapahit empire fron gongs made in Siam.

It frequently happens that cracks and other cavities are formed in the gong during forging, due to residual slag or impurities in the lakar. If the fissures are only of a superficial nature, these defects are hewn out with a petel, or for larger breaks with a banci. The petel is the common adze of the Javanese carpenter, the banci a small iron hammer much like a mattock, with a sharp striking edge.

This hacking process is called matuk, and the metal chips thus produced are called patukan. The latter may be appropriated by the panji. If a fissure cracks through the entire thickness of the metal or an actual hole occurs, this is filled with bronze in a very ingenious manner by means of the a-cire-perdue (1ost wax) process.16

The crack is first 1 ined on both sides with beeswax (mazam), then is warmed with a glowing-hot iron, and the melted wax completely fills the cavity.

On the upper surface of the gong along the fissure is stuck a sma11 roll of wax (pelur) which bears on each end a vertical, forked wax piece. The one with a funnel head represents the position of the later entrance channel, the other that of the exit channel, for the melted alloy to be poured in (see Figure 8). The gong with this wax construction on top is now completely covered with black form-loam, on top and underneath, until a small conical pile is formed. This formloam is a mixture of loam with old, crushed kowi (melting crucible). Above the mouth of the entrance-channel is made a funnel-shaped open-

16. Concerning this and other processes, see F. von Luschan's article, "Alterthümer von Benin," Verhandlungen der Berliner Gesellschaft für Anthropologie Ethnologie und Urgeschichte, XXX (1898), pp. 150ff. 
ing, while the exit channel opens on the side of the loam pile (see Figure 9). The entirety is fired until it is hard, while the wax melts from the heat and drains out.

While this form has been being constructed, some bronze alloy has been meanwhile melted down in a small melting crucible. This liquid mass is then poured into the funnel mouth of the conical pile, until an excess amount drains out through the exit channel. By this procedure all the air is expelled out of the form and the crack completely filled with metal. The exit channel is then stoppered with a small clay cone on the end of a short stick, in the same way as is done on a larger scale in a blast furnace. Finally the metal in the form is allowed to cool.

After breaking and removing the form, the overflow is hacked away with a petel. The part frozen in the entrance channel has assumed the shape of a cone with a handle, and is called tanjak. This is regarded as having medicinal value by the Javanese; the water in which a tanjak has lain is a good remedy for coughing.

This described method of using the lost-wax process to correct cracks and holes is called di nyingeni. Whatever metal is left over as a byproduct, including the tanjak, belongs to the panji.

Holes of only very slight importance and small cracks on the inner side of the gong are simply filled with telutuh to (the resin of the 2o-tree), 17 after which this is warmed with a hot iron rod until it melts and completely fills the crack. It is gathered and stored in small bamboo tubes, and has the property of becoming unusually hard after some time. Occasionally a mixture of this resin with rice and finely ground pitslag is used for the same purpose. This process is called nyamari.

The gongsmiths have their own names for the various shapes which the gong assumes in different stages of the forging. These successive forms are shown in Plates IX, X, and XI.

If we begin with the first shape that the pounded-out lakar assumes, the gongsmith distinguishes among four different intermediate forms, before the workpiece finally corresponds to the name gong. These four stages are called:
1) gong jero Zolohan
2) gong jero nyanduk
3) mbaleni rai
4) gong wis ngejor

The first two intermediate stages following the lakar, in which the sidewall is not yet shaped, are subsumed under the generic name gadangan; stages 3 and 4 , in which the sidewall is visible, are similarly termed kiontongan.

17. See Sijfert Hendrik Koorders and Th. Valeton, "Bijdragen tot de Kennis der Boomsorten van Java," Mededeelingen uit 's Lands Plantentuin, XI (1895). In this work the Linnaean name of the 10 tree is given variously as ficus lanceolata HAMILT. (p. 211) and Ficus glomerata ROXB. variety elongata KING (p. 272). 


\section{The Voicing and Tuning}

After the gong has been forged, it is finished (polished) and at the same time tuned.18 These two tasks always actually occur simultaneously, in the sense that each time the gong must be retuned if it has "gone out of tune," as we would say, during the finishing.

It has been. written elsewhere that one method for tuning the gong is filing down the pencu. ${ }^{19}$ In Semarang, however, this is not done; when asked about it, the gongsmiths emphatically declared that this was not the correct way--although a deeper tone would be obtained, the gong would actually be ruined, because filing would permanently reduce not only the thickness of the metal but also by this any possibility of any later desired change of tone.

The method used by the gongsmiths of kampong Gendingan solely consists of cold-hammering the face of the gong, on the inside as well as the outside. Presumably the elicited changes in tone are a consequence of the greater or lesser vibration of the different parts of the surface of the gong produced in this manner.

The Javanese call the voicing wehana swara. What the gongmaker understands as nglaras is the tuning of the different instruments of the gamelan so that they are in a prescribed tuned relationship with each other. 20

Our inquiries about voicing and tuning did not produce fully satisfactory results, because the tuner himself was almost entirely unable to account for the "how" and "why" of his methods. There were several hard rules that he was able to give, however, which are enumerated below.

The gongmakers, by the way, also regard the voicing and tuning as the most difficult part of their work. Only a few are skilled at this, and it depends more on sudden inspiration, experience, and especially trial and error.

The first tuning of the forged and completely cooled gong is provisional, as it will likely be affected by later refinishing.

The required tools for this tuning are the previously mentioned penunggalan and an anvil made of kesambi-wood, called tunggak. It is in the form of a block about 50 centimeters high, whose top is rounded.

When the smith pounds with the penunggalan on different parts of the gong, on the inside as well as the outside, its timbre and pitch change in a truly remarkable way (see Plate IV).

The smith begins by pounding on the inner or outer side of the rai. These are extremely strong blows and are all about the same distance from the center, thus describing a circle. Each time after

18. TN: "Stemmen" is the term actually used by the authors. However, the process described involves adjusting not only the pitch but also timbre, intensity, and number of beats, hence the inclusion of "voicing" in the translation.

19. See de Does, "Toestand der Nijverheid."

20. TN: Concerning laras, tuning system, see Kunst, Music in Java, and Mantle Hood, "Slendro and Pelog Redefined," Selected Reports, I, No. 1 (1966), pp. 28-48. 
several blows on the gong lying on the tunggak, the tuner tests to see if the desired sound (swara) is produced, for which he strikes the boss with his fist or the proper gongbeater (tabuh).

With similar testing the pasu and the rejeb also are worked with the penunggalan, inside and outside, until the desired pitch and timbre are finally obtained.

Now here are some explanations by the gongsmith himself about the method of tuning.

If the sound of the gong has reached its greatest strength and one continues to pound on the same part of the face on the same side (for example, the inner side of the rai), the sound will disappear. The sound can likewise be made duller by giving several blows to the opposite side of the gong (here, in our example then, the outer side of the rai).

Pounding the rai on the inner side is called njuluk and raises the pitch, which is termed kenceng; pounding the outer side of the rai, which lowers the pitch (termed kendo), is called ngendak. Hammering the inner side of the pasu, di masoni, lowers the pitch, while pounding the outer side of the pasu, di pepeh, raises the pitch. Pounding the inner side of the rejeb, which raises the pitch, is called mancali; pounding the outer side of the rejeb, called di kirih ake, increases the number of beats audible during the sounding of a gong.

These beats are called ombak ("waves") in Javanese, anggu in Malay.21 There are also gongs which have no beats when sounded, and the Javanese then say that they have swara siji and term them gong baung.

Opposed to these are the gongs which have a greater or lesser number of beats, and it is said of them that they have ombak akeh (or swara akeh).

The gongsmiths distinguish gongs according to their number of beats. They say that one can give a gong a maximum number of beats according to its size.

The bonang and other percussion instruments in the gamelan have no beats--they must all be baung. On the other hand, the true gong belonging to a gamelan must have many.

A similar preference for numerous beats is true of buyers of gongs from the other islands of the archipelago. It is usual for the gongsmiths in Semarang to produce a certain number of anggu in a gong destined for a particular market. The smiths informed us that gongs with three beats are preferred in Samarinda, and with as many as possible in Makassar.

Among the gongmakers there is a saying that a gong loses an ombak (beat) each year whether played or not until only one steady tone remains, and thereafter gains back one beat each following year.

21. TN: See Kunst, Music in Java, I, pp. 140-41; Ray Giles, "Ombak in the Style of the Javanese Gongs," Selected Reports, II, No. 1 (1974), pp. 158-65. 
This altering of the sound or number of beats of a gong can probably be considered as the consequence of the gradual modification of the molecular condition of the metal.

New gongs being played must be retuned after some time, and thereafter once each year, for a total of three times. After the third tuning the pitch and the number of beats remain constant, according to the gongmakers. However, this point certainly needs more exact confirmation.

When the provisional tuning has been finished, al1 dents and irregularities present along the circumference of the edge of the gong are then pounded out on a small iron anvil (the paron) with a small iron hammer, the cocor seletan. This process is called selet.

Two holes are now bored ( $d i$ jara) some distance apart in the sidewall of the gong for the rope by which the instrument is hung. For this the smith uses a drill, grebeg, which is constructed in the following manner (see Plate VI).

In a wooden staff, which has a brass cap with a ring on the upper end and a brass ferrule on the lower, is fastened a flat triangular iron gimlet (antap). A heavy lead disk is mounted horizontally somewhat above the lower end, and above that the staff passes through the center hole of a wooden crosspiece on whose ends is fastened a rope that passes through the ring on top.

When the crosspiece is repeatedly moved up and down along the length of the staff, the rope is alternately wound and unwound around the staff and thus imparts to the drill a turning motion, alternately to the right and left. The lead disk serves as a flywheel.

The final stage in the manufacture of a gong has now been reached, in which the purpose is principally to give it a better appearance. The surface of the gong is still black and extremely uneven, just as it came from forging. The gong is filed (ngikix), planed (ngesik), or turned (bubut), and this brings out the yellow color of the bronze and makes the surface smooth and shiny (see Plate V).

This is done to the boss only, or to the boss and the outer surface of the instrument. The worker in charge of the finishing is called tukang kikip or tukang gilap (gizap = "to shine").

For filing the sidewall of the gong, the instrument is placed upright in a pit whose depth is half the gong's diameter.

The gongmakers buy the files at auctions of old, used tools of the military workshops; they do not regard other tools as being suitable in quality. These files are then changed into curved rasps (platar)22 with very coarse teeth and set in a wooden handle. The urik-urik is a small tool used for sharpening the teeth of these rasps, consisting of a short steel rod in a wooden grip.

The fine bronze shavings produced as a byproduct in filing are called awon and constitute a well-known means of poisoning. For this purpose it is crushed to a very fine powder and regularly added in small amounts to daily meals. The gongmakers claim they have had con-

22. Patar in Banjumas, according to de Does, "Toestand der Nijverheid." 
stantly repeated inquiries about this awon from other natives and Chinese (mostly women), and in a few cases, even from Indian ladies. The gongsmiths themselves, however, are not fully convinced of the harmfulness of awon for health.

It is further believed that the banyu plandan, the dirty, muddy water from the pit (plandan) in which the gongs are cooled, is an antidote for awon poisoning. 23

Planing the surface of the gong, which removes scratches produced in filing, is done with two tools, the pangur and the pengesik. The pangur is a meter-1ong wooden beam in whose approximate center is perpendicularly set a sharp chise1. The worker rests one end of the beam on the ground as a fulcrum, while he planes the gong's surface with the chisel by moving the other end. The pengesik is a sickle-shaped blade whose two ends are both set in a single short wooden handle. The left and right projecting ends of the handle are held with both hands, and the surface is planed with the blade. (Both tools are shown in P1ate V.)

A gong is rarely turned, and then only if it is a particularly beautiful and expensive piece for the gamelan. For this is used a primitive lathe (bubutan or undan-undan), which was invented in more recent times, according to the smiths in Semarang (see Figure 10).

On four short stakes rests a rectangular frame of four beams. In between and parallel to the two end pieces is a moveable crossbeam, whose position between them can be adjusted by sliding its ends along the length of the frame. Two iron bolts are attached, one in the middle of one endpiece and the other opposite it, in the middle of the crossbeam.

In order to hold the gong in the lathe, a small board is placed inside the rear hollow of the instrument, whose concave sidewalls hold fast the ends of the board (see Figure 11). A second, somewhat longer board is next laid across the back of the gong above the first, and the two are fixed together with two spanners. Through corresponding square holes in the center of both boards is inserted a wooden axle, which bears on its outer end an hourglass-shaped spindle (suwe 2 ). On the outer end of this spindle is mounted an iron disk with a central hole. The entire assembly is now placed in the lathe so that the bolt in the stationary endpiece is inserted into the hole in the end of the spindle. Then the adjustable crossbeam is moved up and set so that the other bolt presses against the center of the pencu and in this way the gong is suspended between the two iron bolts, called incer.

A long bamboo pole is planted in the ground at some distance from the lathe. A long thin rope fastened to its upper end passes down to the spindle, where it is wound several times around and then down to a pedalboard under the lathe, to which its other end is attached. When the pedal is depressed, the spindle (and gong) are turned, while the

23. TN: Concerning mythology, legends, and beliefs about gongs in Java, see the following: Anonymous, "De Wassching van de Heilige Gong te Lodojo," Weekblad van Nederlands-Indië, IX (1912), pp. 202-3; Soepardi-Handajakiswara, "De Heilige Gong van Lodojo (B1itar)," Jong-Java, V, No. 3-4 (1920), pp. 124ff.; Mantle Hood, "The Effect of Medieval Technology on Musical Style in the Orient," Selected Reports, I, No. 3 (1970), pp. 148-70; Kunst, Music in Java, I, pp. 140-41, 150-53, 257-74 passim; II, p. 586 . 
bamboo pole is simultaneously bent down and stretched. When the pedal is released, the pole strains to return to its vertical position and turns the gong in the opposite direction.

Blades are used to finish the surface of the gong as it is turning, and the adjustable crossbeam acts as a support.

After the gong has been finished it is once more tuned and is then saleable.

Here we should mention a characteristic decoration which is produced on certain gongs, especially those made for Kutei. As shown in Figure 12, this consists of a star made of eight isoceles triangles, with the pencu as the center. The rays of the star--the apexes of the triangles--reach out to the pasu. The pencu itself is brightly polished, while the triangles and their inscribed lines are sharply incised with the pangur and the exposed metal brightly burnished. Occasionally the decoration is simply outlined and the rest left black like the surrounding surface of the gong. There are always eight triangles in the same shape. In Java itself this kind of gong is not used.

Finally, we should make several remarks here about the financial and economic sides of the trade. The workers' wages are extremely high for a native; besides this, their earnings are augmented by some profit from selling the different metal byproducts which they may keep. We have already seen that the tanjak and the patukan are appropriated by the panji, while the small pieces of metal (kenyi) within the slag (krawa) as well as the jujutan and getakan belong to the helpers (rewang). The filings (awon) are kept by the tukang kikir, who smelts and then returns this to the gongmakers for 0.65 guilders per kati. The fixed wages are paid on a piece basis (borongan) and not by day (harian); only the apprentices receive a daily wage of 40-50 cents. A price of 2 guilders per pikul is paid for alloying the copper and tin, while melting the metal for pouring a lakar costs $2.5-3$ cents per kati. Below is a table of the wages paid for the forging of gongs of different sizes.

\begin{tabular}{|c|c|c|c|c|}
\hline Gong Weight (kati) & 5 & 10 & 25 & 50 \\
\hline $\begin{array}{l}\text { Number of Gongs } \\
\text { Produced per Day }\end{array}$ & 4 & 2 & 1 & 1 gong in $2 \frac{1}{2}-3$ days \\
\hline First Panji & f 0.30 & f 1.00 & f 1.50 & $f 6.00$ \\
\hline Second Panji & - & - & - & 6.00 \\
\hline Malu Ngarep & 0.30 & 1.00 & 1.40 & 4.00 \\
\hline Malu Nempong & 0.25 & 0.835 & 1.25 & 4.00 \\
\hline Malu Ngalap & 0.25 & 0.75 & 1.00 & 3.00 \\
\hline Malu Nulup & - & - & 1.00 & 3.00 \\
\hline Nulup & - & - & 1.00 & 3.00 \\
\hline Ngaroni & 0.15 & 0.40 & 0.75 & 2.50 \\
\hline Ngalap & - & - & - & 3.50 \\
\hline
\end{tabular}

For the number of gongs that can be produced per day, in the second row of the table, it must be taken into consideration that only half a day per gong is needed for the actual pounding, while the previous casting and subsequent tuning comprise the rest of the work. No wage is paid for gongs which break during the work; these are melted down and cast again. This does not occur very often, however; one misforged gong per week is considered to be a lot. 
The wages of the tukang kikir for the filing are not included above. His work is considered separately and rated in the following manner:

\begin{tabular}{|c|c|c|c|c|c|}
\hline & & Gong & ght & ti) & \\
\hline & 5 & 10 & 15 & 25 & 35 \\
\hline - & f 0.35 & 0.50 & 0.75 & 2.00 & 2.50 \\
\hline ly the Bos & f 0.03 & 0.05 & 0.05 & 0.10 & 0.15 \\
\hline
\end{tabular}

2.5 cents per gong is paid for boring the two holes for hanging.

The gongs sold in trade are of two qualities. The majority are worked very roughly, but there is also a better kind which is carefully forged and exactly fashioned. More time is required to make these and consequently they are more expensive. Few orders are placed for this better kind, however; a gongmaker is seldom commissioned to make such gongs, except by the Javanese rulers in Solo or Yogyakarta or by re gents or rich Chinese. The less carefully crafted gongs go exclusively to the islands outside Java (the Buitenbezittingen) and are consequent ly called gong sabrang, while the better ones remain on Java itself.

The current prices for the cheaper quality of gongs are:

Gong Weight (kati)

\begin{tabular}{ccccc} 
& 18 & $20-23$ & $25-28$ & $30-35$ \\
\cline { 2 - 5 } Price per Kati 1.20 & 1.30 & 1.35 & 1.42
\end{tabular}

(only the boss polished)

For the better quality of gongs sold in Java the prices are:

Gong Weight (kati)

\begin{tabular}{|c|c|c|c|c|}
\hline & $30-35$ & $40-43$ & $45-48$ & $50-55$ \\
\hline Price per Kati & f 2.00 & 2.30 & 2.50 & 2.75 \\
\hline
\end{tabular}

24. TN: Current information on gongmaking was given to the translator in an interview in May 1969 by Rekso Wiguno of desa Wirun, subdistrict Mojo Laban, several miles outside Surakarta. This gongsmith is at present the leading manufacturer of gongs in Central Java, working both privately as well as on a commission basis for Leppin Karya Yasa, the recently organized gamelan industry associated with the Mangkūnegaran of Surakarta. For a newly forged gong of 85 centimeters diameter, weighing 35 kilograms, the prices are as follows: polished boss only, Rp. 60,000 ( $\$ 160)$; completely polished, Rp. 65,000 (\$173). Such a gong requires ten days of work by a group of six smiths. Polishing the entire gong requires one man working alone for one month. The technology for forging gongs over one meter in diameter has been lost due to a large decline in the trade. Over the past ten years Rekso Wiguna and his assistants have succeeded in producing gongs up to 94 centimeters in diameter. Regarding reinforcement of the gong industry in general and this gongsmith in particular, see Mantle Hood, The Ethnomusicologist (New York: McGraw-Hi11, 1971), pp. 363-68. A recent paper on gongmaking by an Indonesian author cites six smiths as sources of information, including the second son of Hama, who currently operates the same smithy in Semarang that is described in this study. See S. Pranoto, "Teknik Pembuatan Gong Besar" (unpublished paper, Akademi Seni Karawitan Indonesia, Surakarta, n.d.). 
An approximate cost analysis of materials and 1 abor for 20 gongs each weighing 5 kati, with polished bosses, would be as follows:

\begin{tabular}{|c|c|}
\hline $\begin{array}{l}100 \text { kati copper } \\
30 \text { kati tin } \\
\text { (approximately } 25 \text { kati lost in oxidation) } \\
\text { charcoal for smelting } \\
\text { charcoal for forging } \\
\text { wages for forging } 20 \text { gongs of approximately } 5 \text { kati } \\
\text { polishing the bosses } \\
\text { boring the holes }\end{array}$ & $\begin{array}{r}4 . \\
5 . \\
25 . \\
0.60 \\
0.50\end{array}$ \\
\hline Total & \\
\hline
\end{tabular}

Thus the cost of making each of the 20 gongs of 5 kati comes to about 6 guilders. Any profit has already been lost, and yet general expenses have not been included in the reckoning. On the current market, one can see that the business would actually be suffering a certain loss if the gongmakers did not cut down the cost of materials by mixing in cheaper, used copper as described earlier. It should be noted that the standard price of a gong is in accordance with the size of the piece, because the difficulty in the work and manipulation is also correlated with the weight.

According to the shape of the piece one distinguishes mainly between gong and tawak. The former has a lower, the latter a higher rim. Tawak are made exclusively for the islands outside Java.

The canang is a special kind of gong; it has no pasu (ledge) and its face is completely flat with the exception of the boss. Two kinds are distinguished, one with a high (less concave) and the other with a low (more concave) sidewall (bau). These are exported to the Lampong district (Sumatra) and Sambas (Borneo).

The weight of a gong lies between one kati and half a pikul.25

The oldest gongmaker in Semarang told us about the remarkable accomplishment of his uncle, Pak Amat Kasan; thirty-five years ago, in accordance with the order of Paku Buwana VII Purbaya, Susuhunan of Solo, he manufactured a gong weighing $1 \frac{1}{4}$ pikul and was paid 1000 (?) guilders.

The manufacture of other instruments belonging to the gamelan is of less significance. These pieces are also primarily made in Solo in kampong Kemelayan.

As we have already stated earlier, not only are gongs purchased and used in a11 parts of Java, but also a large number goes to the other islands of the archipelago and to Singapore. From this latter port a significant number is again exported to Borneo and the entire Malay peninsula. Berouw, Bulangan, Kayeli, Serawak, Brunei, and many other places in the archipelago obtain their gongs not directly from Semarang but rather have brisk trade relations with Singapore.

25. According to the gongmakers of Semarang, a gong weighing 5-6 pikul, such as the one mentioned in G. P. Rouffaer's De Voornaamste Industrieën der Inlandsche Bevolking van Java en Madoera (The Hague: Nijhoff, 1904), p. 98, could never be manufactured. 
An important trade item is the bende, which is used throughout the East Indies as a signaling device--at the houses of headmen, in watchhouses and on plantations, for sounding the alarm or to call people together in the event of a fire, amok or other dangers, as well as for striking the hours during the night-watch. Further, the beginning of public auctions everywhere in Java is still announced by strokes on a bende.

Mostly gong and tawak of 4-10 kati go to the outer islands, while to Bali and Lombok, for example, are sent gongs of greater weight.

Makassar, Sumbawa, Banjarmasin, Pontianak, Samarinda and many other places are regular buyers of the Semarang product. Throughout the entire archipelago the gongs are used not only for signaling but also as musical instruments for festive occasions and as accompaniment for dance.

On several islands in the archipelago the gong is also used on boats to sound out the rhythm for the oarsmen.26

On Borneo, the Aru Islands 27 and many others they serve as a means of payment, so that on Borneo, for example, gongs, old pear $1 s^{28}$ and tempayang 29 constitute the principal wealth of well-to-do Dayaks.

Several interesting observations about the present-day gongs from Serawak are found in a work by $R$. Shelford. ${ }^{30}$ One of these concerns the characteristic manner in which a cast gong from Kucing is given the appearance of a pounded Javanese gong--by producing counterfeit hammer marks on the wax model before the mold is made.

The name kromong mentioned in the same work is completely unknown to the gongmakers in Semarang; they have never previously heard of it.

The cast canang of Serawak and Brunei are often very beautifully decorated (for example, the canang naga); ${ }^{31}$ the pounded Javanese canang are of course never decorated.

26. See W. Joest, "Malayische Lieder und Tänze aus Ambon und den Uliase (Molukken)," Internationales Archiv für Ethnographie, V, No. 5 (1892); Karl Bücher, Arbeit und Rhythmus (3rd ed.; Leipzig: B. G. Teubner, 1902), p. 204; ibid. (6th ed.; Leipzig: Emmanue1 Reinicke, 1924), pp. 234-35.

27. Also used here for payment of dowry. Compare with H. 0. W. Planten and C. J. M. Wertheim, "Verslagen van de Wetenschappelijke Opnemingen en Onderzoekingen op de Key-Eilanden Gedurende de Jaren 1889 en 1890," Tijdschrift van het Koninklik Aardrijkskundig Genootschap (Leiden: E. J. Brili, 1894), yearbooks 1892 and 1893 , pp. 2-12 (a description by C. M. Pleyte of a wooden board used as a record of a bridal dowry, on which are incised figures of lilacs, ear-and arm-jewelry, and also gongs); and the accompanying Ethnographische Atlas van de Zuidwester- en Zuidoostereilanden by C. M. Pleyte, Plate XVII, Figures 3 and 4.

28. See A. W. Nieuwenhuis, "Kunstperlen und Ihre Kulturelle Bedeutung," Internationales Archiv für Ethnographie, XVI (1904), pp. 136-56 and Plate XIX.

29. The so-called "sacred water-jars." See George Alexander Wilken, Het Animisme bij de volken van den Indischen Archipel (Amsterdam: De Bussy, 1884), p. 131.

30. See R. Shelford, "An Illustrated Catalogue of the Ethnographical Collection of the Serawak Museum, Part I: Musical Instruments," Journal of the Straits Branch of the Royal Asiatic Society, XL, No. 46, 49 (1904).

31. See the illustration of a gong bernaga of the Tebidah Dayak in the district 
The intermediate trading to Singapore and the islands outside Java lies fully in the hands of the Chinese and Arabs, except for several buyers in Buleleng ( $\mathrm{Bali}$ ), with whom the gongsmithies in Semarang deal directly.

Several times a year Buginese shippers come with their praus from Makassar and Buton to Semarang in order to trade their cargo of dyewood, nipa-leaves, mats, and the like for other wares with Chinese traders, at which time they also regularly purchase gongs.

In general, the gong trade has declined very much in comparison to earlier years. ${ }^{32}$ The cause of this is not exactly clear but is probably due to a certain extent to the popularity of the cast gongs which are currently made in several regions of the archipelago, as given for Serawak in the work by $R$. Shelford.

Exact conclusions concerning sales on Java and exportation to other places were unable to be reached; the statements of the gongmakers agree so little with those of the Chinese and Arab traders overall that they hence clearly can be given little credence.

Sintang, West Borneo, in A. B. Meyer, Alterthümer aus dem Ostindischen Archipe1 uber Angvenzenden Gebieten, unter besond Berücksicht (Leipzig: A. Naumam $\xi$ Schroeder, 1884), p. 7 and Plate XI, Figures 3 and 4 . The face of this gong is adorned with a bas-relief of two snake-dragons and a wave-motif. Compare with J. D. E. Schme1tz, "Bronzepauken im Indischen Archipe1," Internationales Archiv für Ethnographie (Supplement), IX (1896), pp. 41-54 and P1ate IV; and the same author's Ethnographische Musea in Midden-Europa. Verslag eener studierreis 19 Mei - 31 Juli 1895 (Leiden: E. J. Brill, 1896), p. 70 and Plate p. 71 (Inv. no. 893/107).

32. See also P. F. Abe11, "Bijdrage tot de Inlandsche Kunstnijverheid van MiddenJava," Tijdschrift voor Nijverheid en Landbouw in Nederlands-Indië, XXXV (1887), pp. $25 \mathrm{ff}$. 
KEY TO THE PLATES

\section{Plate I}

View of the interior of the smithy at the moment when the gong is reheated in the hearth during forging.

The light circular place in the background is the crater-like opening of the pit-hearth (prapen) bordered on its right by a pile of charcoal.

The panji, the master of the work force, sits on the ground before the fire with his legs in a pit and handles the workpiece in the fire with two peryukat, which rest on the wood plank in front of the hearth during the forging.

To the right on a lower part of the ground sit two helpers (nulup and ngaroni), who work the two bellows. If a large gong is being made, the large hearth is used whose air channel (dungu) has two pipes or suling, to each of which is attached a bellows.

Immediately to the left of these two workers is the inset anvil, watu mindan, on the edge of the raised part of the ground. In front of this stands the commonly used iron hammer (palu).

Somewhat farther to the left of the watu mindan, set into the ground is the small water basin (kobokan), near which lies the brush of padi stalk (kobyok).

Close by the feet of the panji is the upper surface of the anvil watu plaraban, near which is the small round depression in the ground in which the boss rests when a gong is pounded on this anvil.

Near the panji lie two pairs of tongs (supit) whose handles are covered with conical pieces of rattan (contong) for protecting the hands; these are used for holding the gong during pounding on the anvil watu tandes, whose somewhat oblique upper surface is visible among the four hammers standing in a circle and resting on boards set into the earth.

On the side of the lowest part of the watu tandes is the mound of loam (ZuIuh) which serves as a support for the gong during pounding.

Sitting to the left in the background is one of the smiths, waiting until the piece is sufficiently heated for forging.

Directly behind in one corner of the smithy is a conical object, a basket woven from leaves and bamboo in which charcoal is carried. To its left stand several round molds for casting the lakar, out of which is forged the gong, and to the right is a half-buried melting crucible (kowi) for smelting the alloy.

\section{Plate II}

A demonstration of the melting of the alloy and casting of a lakar.

At the left is the pit fully filled with charcoal, in which is buried the crucible containing the metal. Directly above it is the opening of the blower for fanning the fire. Sitting on the ground to the right is the man who works the bellows ( amus); the air streams through the bamboo tube (suling) obliquely positioned above, which rests on stones. At the end above the fire is fastened the earthen tube congklok, joined to the conical popokan which directs the air to the long nozzle telale, which is likewise fired clay. In the background stands the worker who removes the slag from the fluid metal with an iron rod. 
Sitting on the ground in the middle is the panji. Using two pairs of tongs, he pours out of a small crucible (kowi cucug) the melted, glowing alloy, drawn from the large crucible, into a penyingan, the round mold in which is cast the metal plate that is the protoform of the gong.

Plate III

The same stage in forging represented in Plate $I$, at the point where the gong, held by the panji with two pairs of tongs, is pounded on the watu tandes by four smiths with their palu. The piece is clearly seen to be resting partly on the anvil and partly on the mound of loam (ZuZuh).

\section{Plate IV}

The procedure called metak, as well as the tuning.

The metak gives the correct shape to the face of the gong; as shown in the photo, it is performed by the two workers in the background.

On a board resting on the ground is the already forged and cooled gong. One of the workers strongly bears down on the long horizontal beam, whose one end is inserted into a wooden pile set in the ground, and thus imparts a strong pressure on the vertical wooden piece umbul and through this onto the gong.

Meanwhile with the small iron hammer cocor selatan the second worker pounds lightly on the gong around the area on which the umbul presses, in order to form the indentation permanently.

To the left in the foreground is the tuner. He has laid the gong on the wooden anvil tungak and is working it with the penunggalan, an iron hammer in the form of a small palu. Near the tuner hangs an iron hook from the ceiling, by which the gong is suspended each time the sound is to be tested.

\section{Plate $V$}

The worker who files the gongs in order to expose the shiny metal surface.

While the gong rests partly in a shallow pit in the ground, the tukang kikir files the boss smooth with the coarse, curved file platar. On the ground before him lies a set of the different tools that he uses: in the middle is the platar, to the left the pengesik, a sickle-shaped planing blade fastened to a short crossbeam, and to the right the short urik-urik with which the file teeth are sharpened. To the right leaning against a post is the pangur, a long stick in which is set a small iron chisel for planing the gong. To the front left is a gong whose entire surface has become shiny from filing.

Plates VI, VII, and VIII show the different tools used by the gong industry.

\section{P1ate VI}

1) umbul dowa, the large wooden cone used for metak.

2) grebeg, the drill with which the holes in the gong's sidewall are bored for hanging.

3) umbul cendak, a smaller version of (1).

4) supit, tongs. 
5) platar, the coarse, bent file.

6) cocor seletan, the smallest iron hammer, used for the work called bentang, i.e., the hammering-out of small dents in smithing.

7) cocor mindan, the iron hammer used for forming the curved sidewall of the gong.

8) banci, the mattock-like hammer with which superficial flaws of the gong are hacked away after the forging.

9) pangur, a chisel fastened on a long stick, used for planing.

10) urik-urik, tool for sharpening the files.

11) penunggatan, a short iron hammer in the shape of the palu, especially used for tuning.

12) pengesik, the sickle-shaped blade used for planing.

13) petel, the common, small native adze, used to pick off small irregularities and close cracks after forging.

14) palu alang, mattock with a long striking-end, used for shaping the pasu (ledge) in the bonang, a gong-kettle musical instrument with a high vertical sidewall.

\section{Plate VII}

1) palu, the large iron hammer with which almost all pounding is done.

2) geblog, a short but very heavy iron hammer with which the Zeleran, the large stock-plate of bronze alloy, is broken up.

3) munjuzan, a wooden hammer whose round head is capped with brass, used for shaping the boss.

4) papak, a large wooden hammer used first after pounding with the iron hammers.

5) contong, conical shield for protecting the hand from the heat of a piece while using the tongs.

6) prapeh, a short wooden hammer used in shaping the curved sidewall of the gong.

7) mason, wooden hammer with which the pasu (ledge) of a gong is produced.

8) penyukat pengiwa, and 11) penyukat gogor, the respectively short and long iron rod-tongs with which the piece is handled in the hearth.

9) Zaga, a boat-shaped wooden hammer.

10) aling-aling, shield with a long handle woven out of bamboo, with which the face of the panji is protected during casting from the heat of the melted metal.

\section{$\underline{\text { Plate VIII }}$}

1) watu jujutan, a stone with a shallow depression, for test-castings.

2) kowi cuoug, small crucible with which the liquid metal is scooped out of the large melting crucible.

3 and 4) a small and a large penyingan, the molds in which are cast the metal plates to be forged into gongs.

5) kowi Zeburan, the small melting crucible used for the second melting of the bronze alloy.

6) batok wesi, iron ladle with a long handle, used during melting.

7) congklok, popokan, and telale, the earthen nozzle made of three parts, which is fastened to the tube of the bellows system during smelting.

8) Zamus, the bellows, a bag of goatskin. 
Plates IX, $X$, and $X I$ show the different shapes which the gong assumes during the stages of work, seen respectively from the front, back, and side.

From the left to right are seen:

1) Zakar, the cast plate of bronze that is pounded out to form the gong,

2) gong jero Zolohan,

3) gong jero nyanduk,

4) mbaleni rai,

5) gong wis ngejor, and finally

6) the fully finished gong.

Forms (2) and (3) are collectively called gadangan; forms (4) and (5), in which the curved sidewall is evident, are known as klontongan.

\section{P1ate XII}

The Semarangan gongsmith Pak Alia (left, standing) and Hama (right, sitting) in formal dress, with several large and small gongs; to the left on the floor are a bonang and a kempul. 


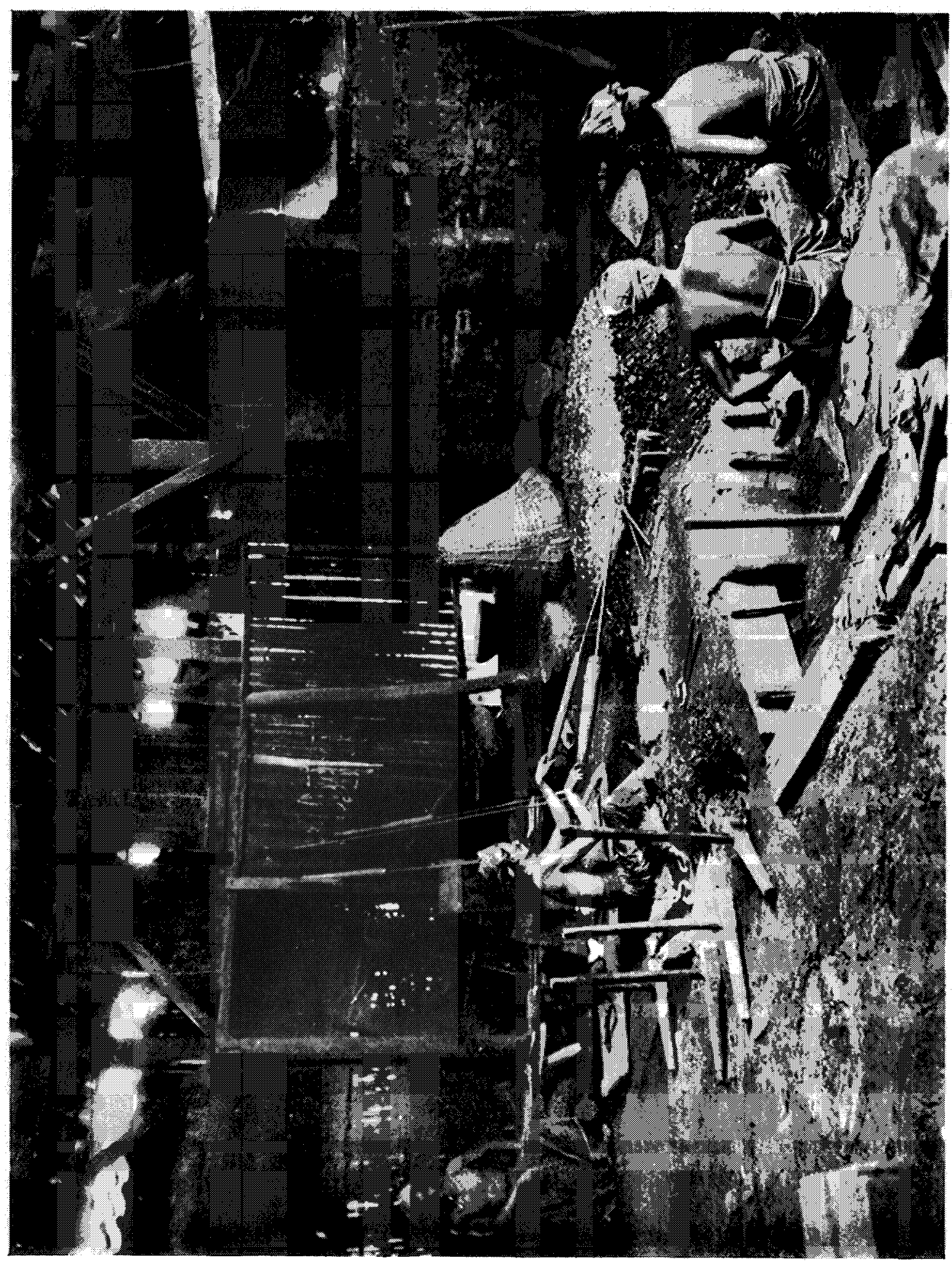

Plate I 


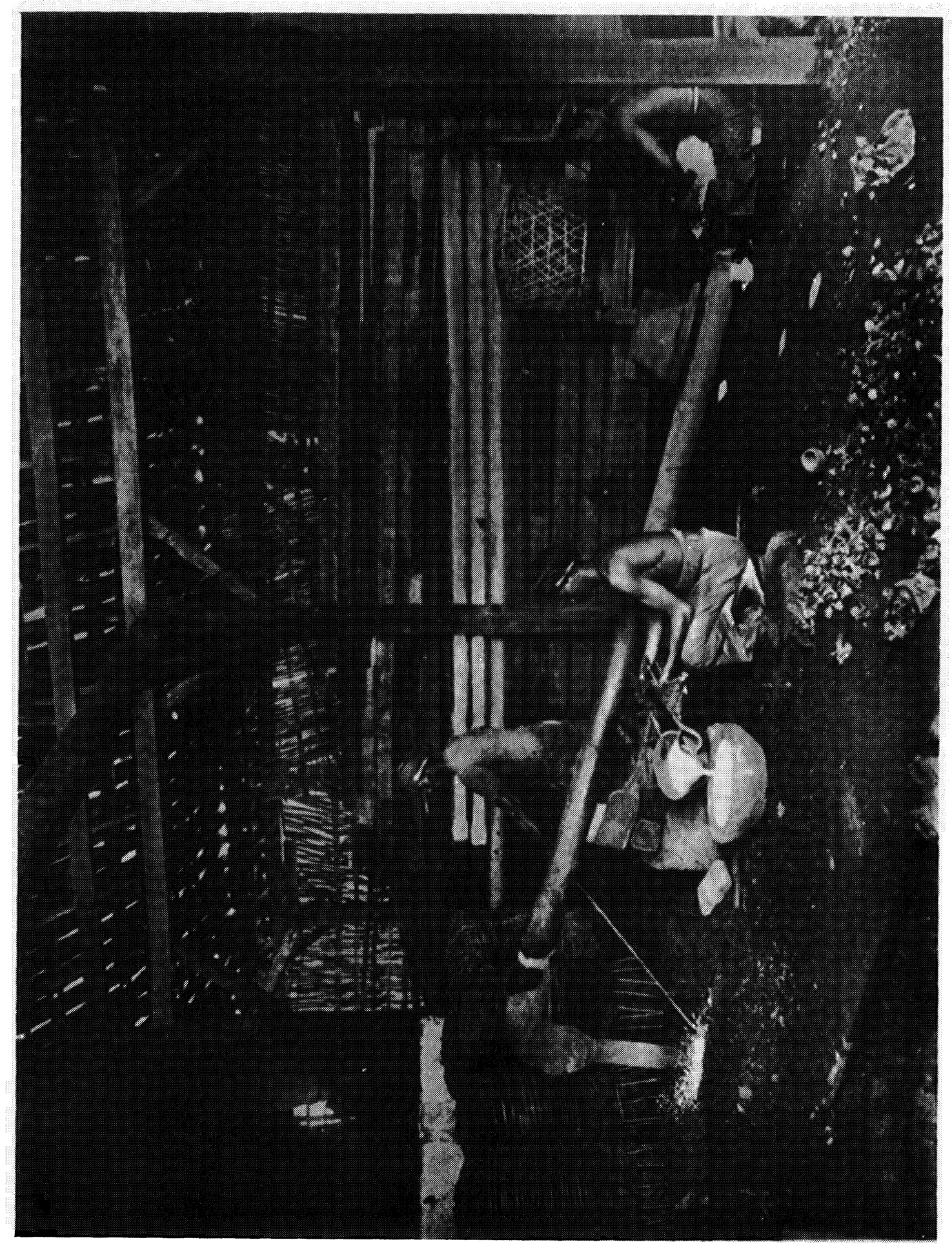

Plate II 


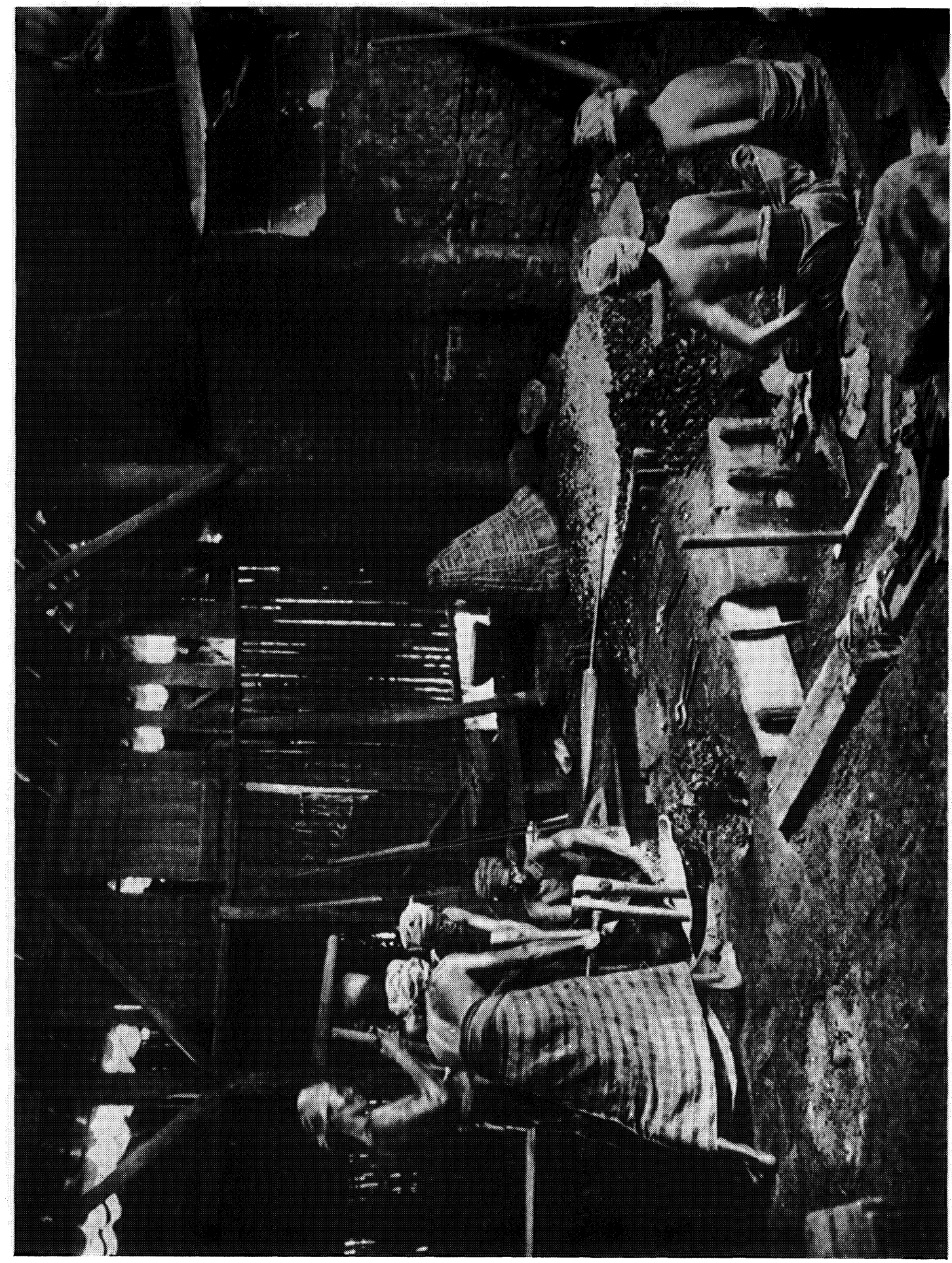

Plate III 


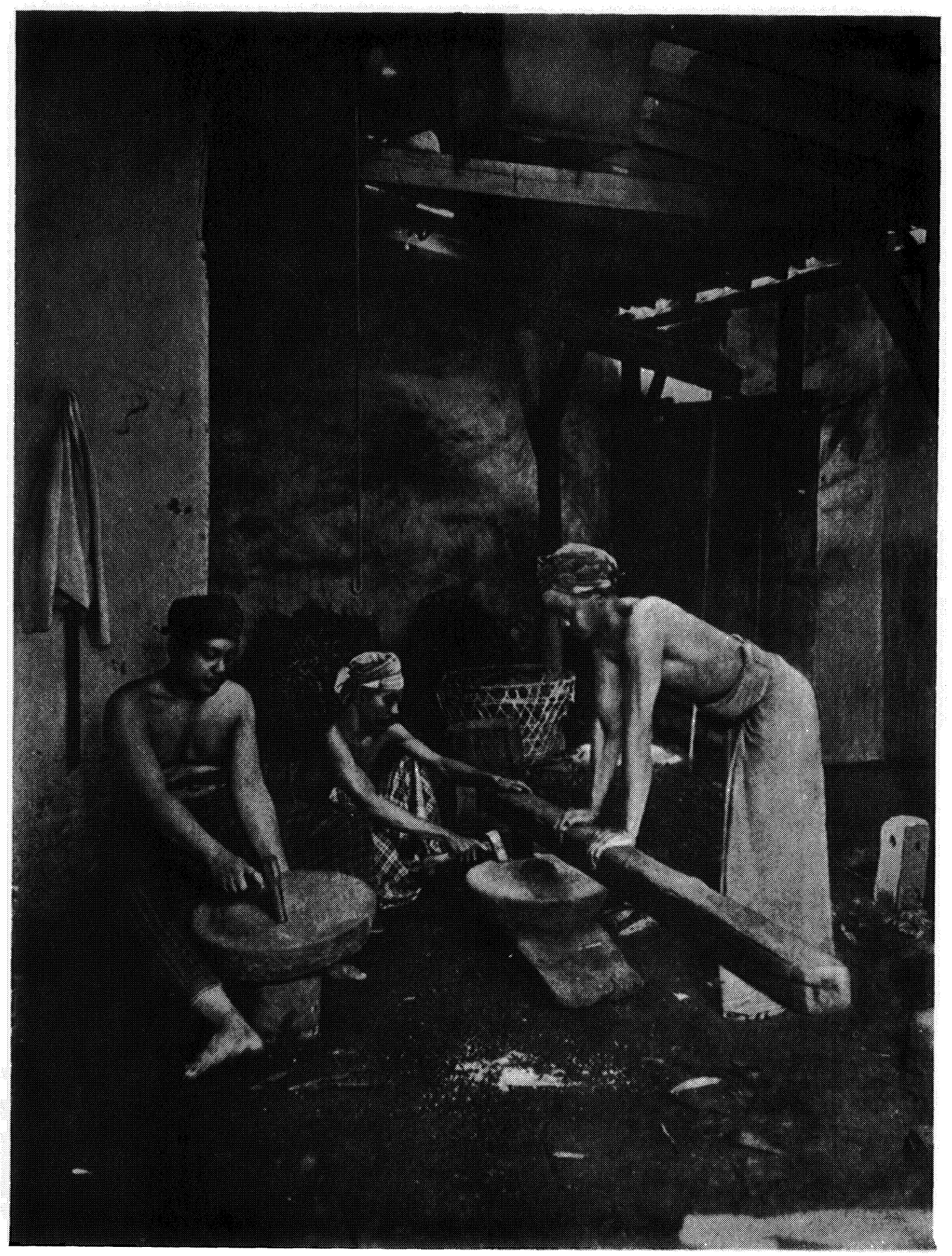

Plate IV 


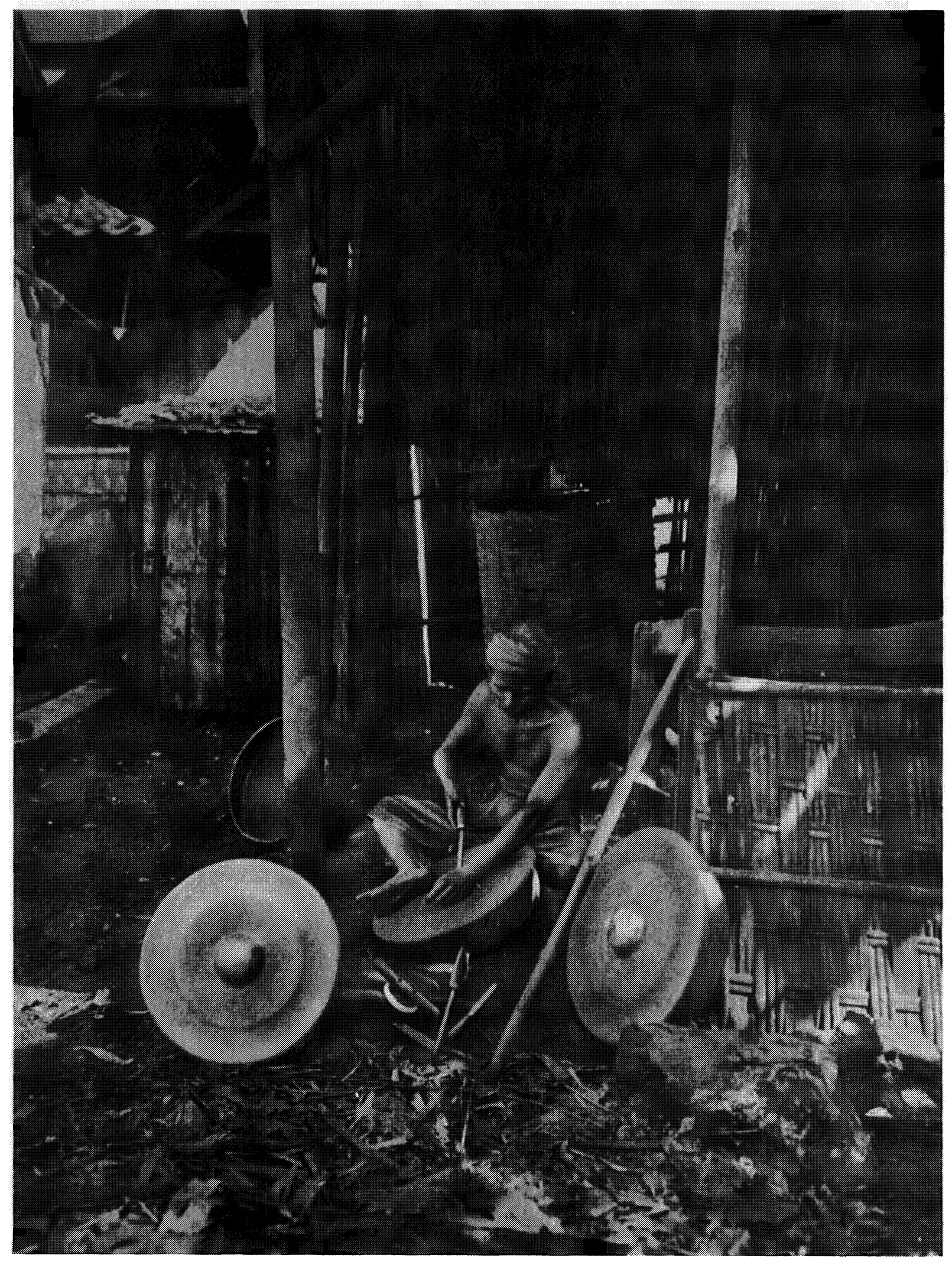

Plate V 


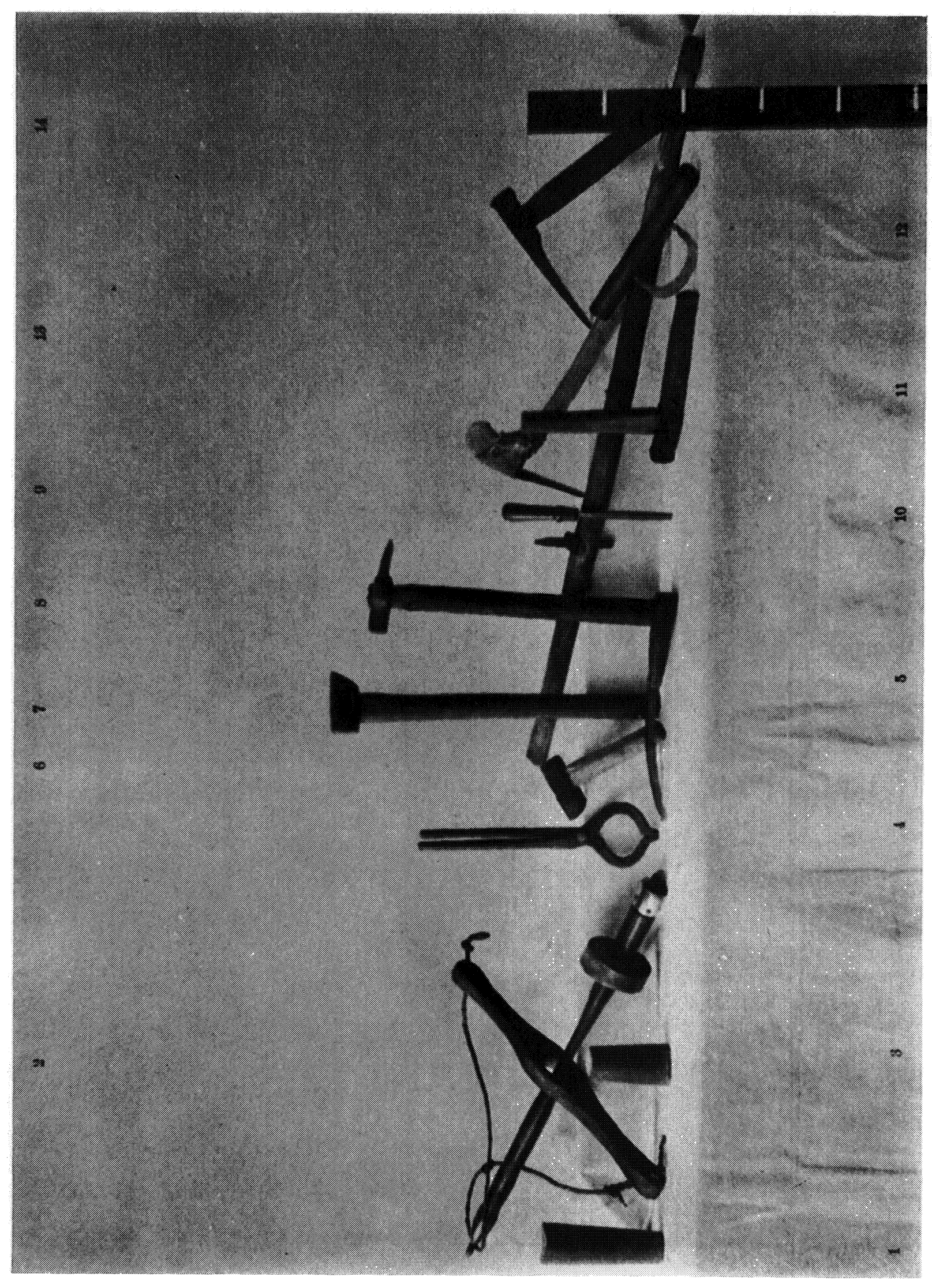

Plate VI 


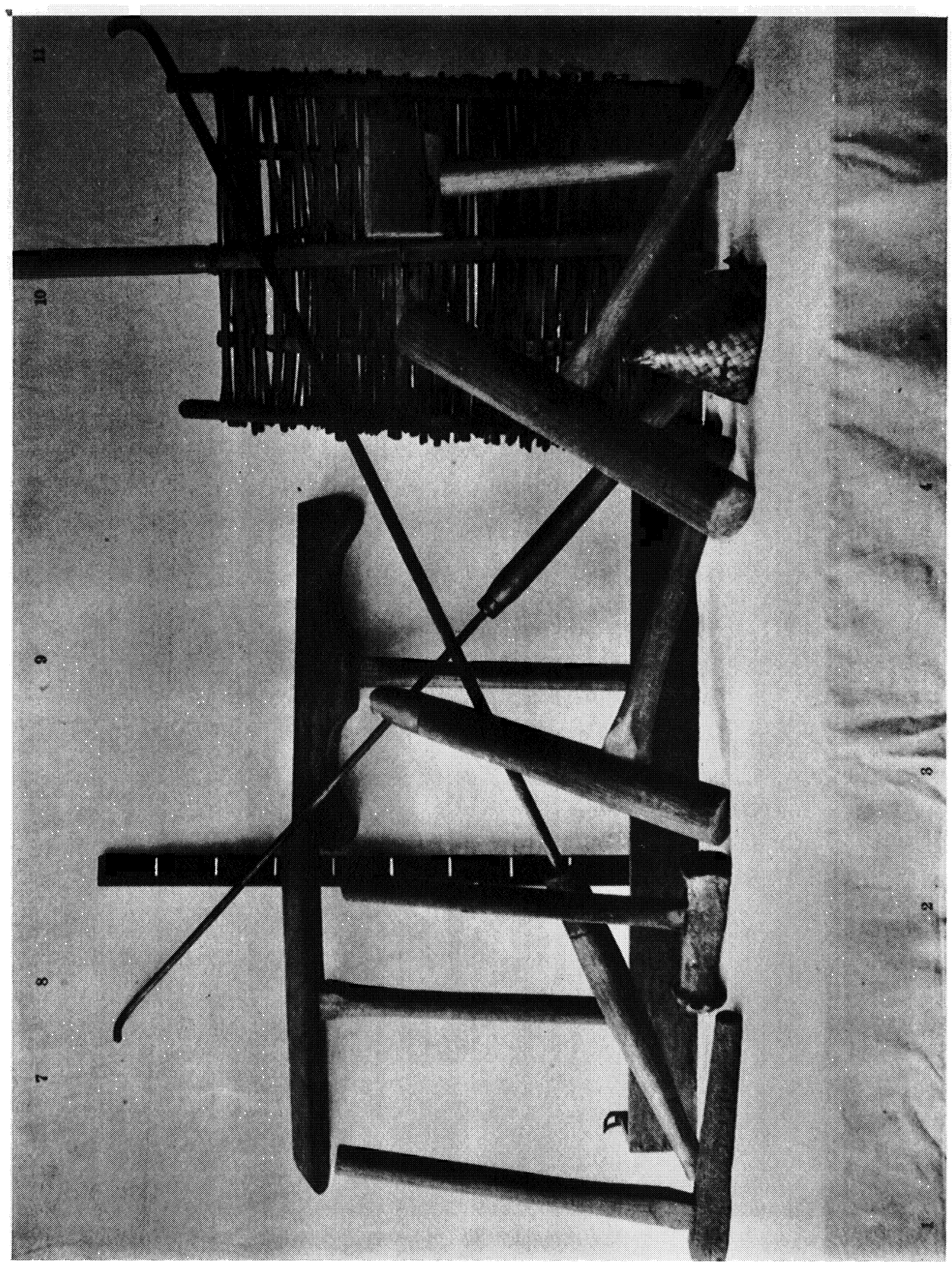

Plate VII 


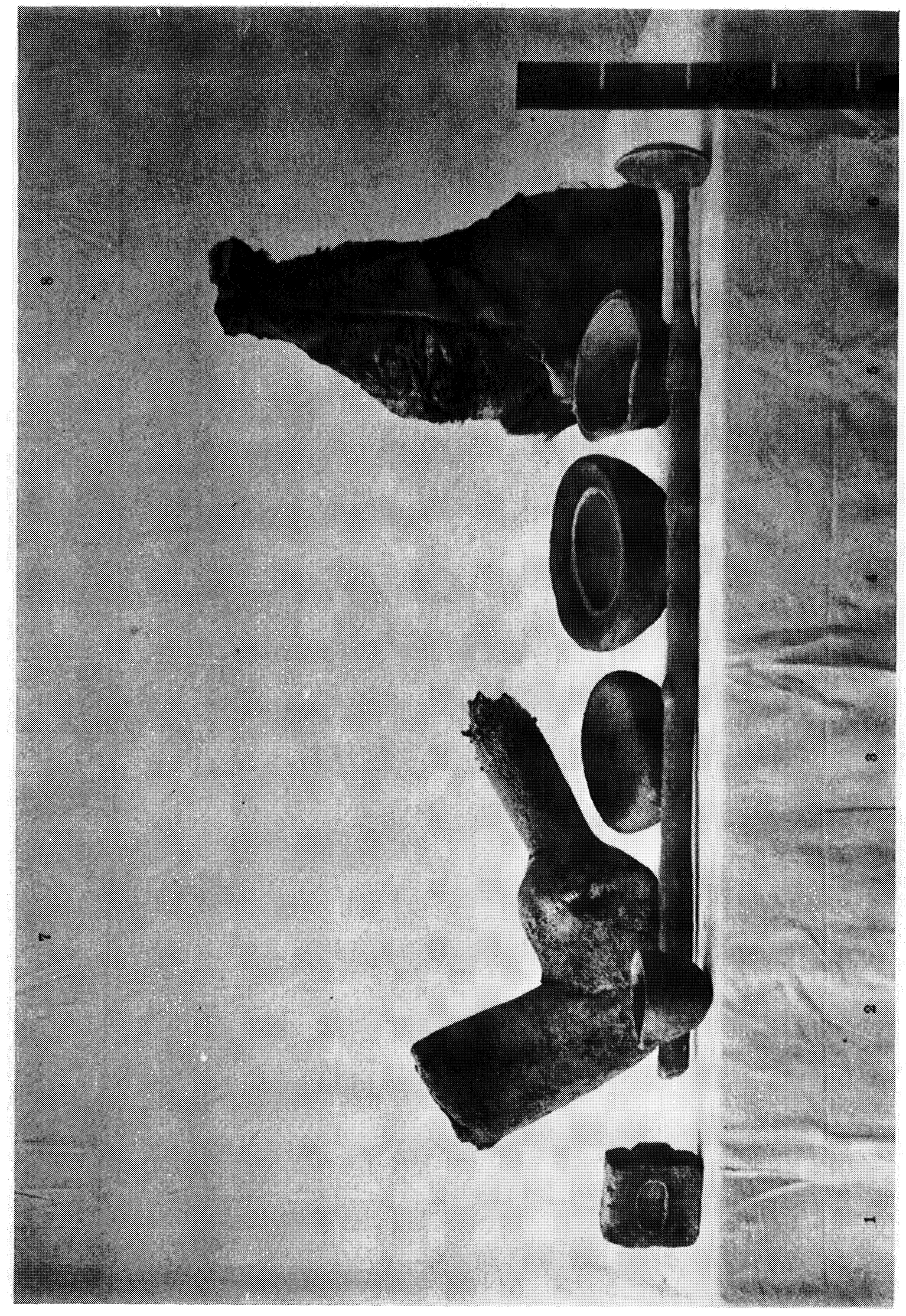

Plate VIII 


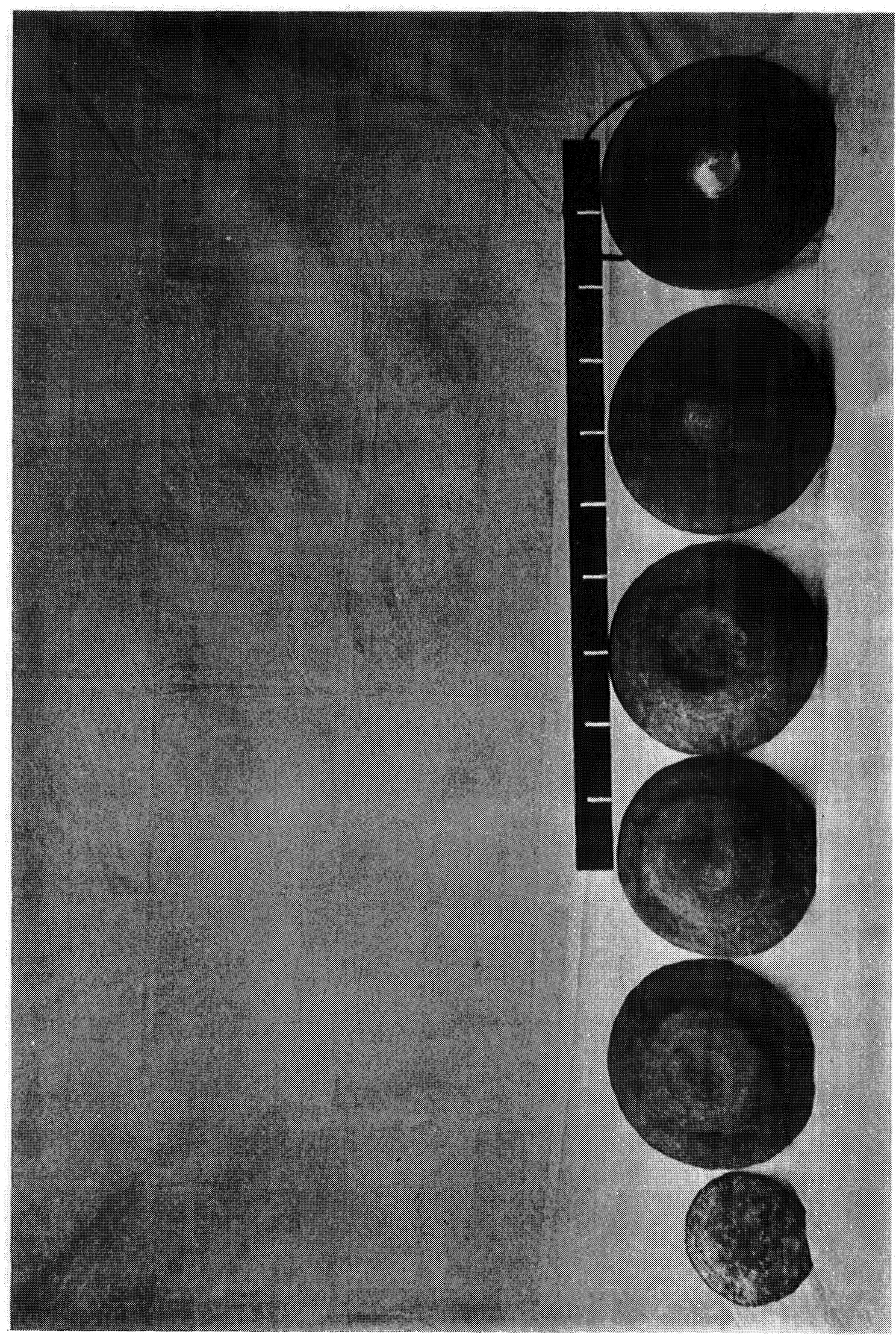

Plate IX 


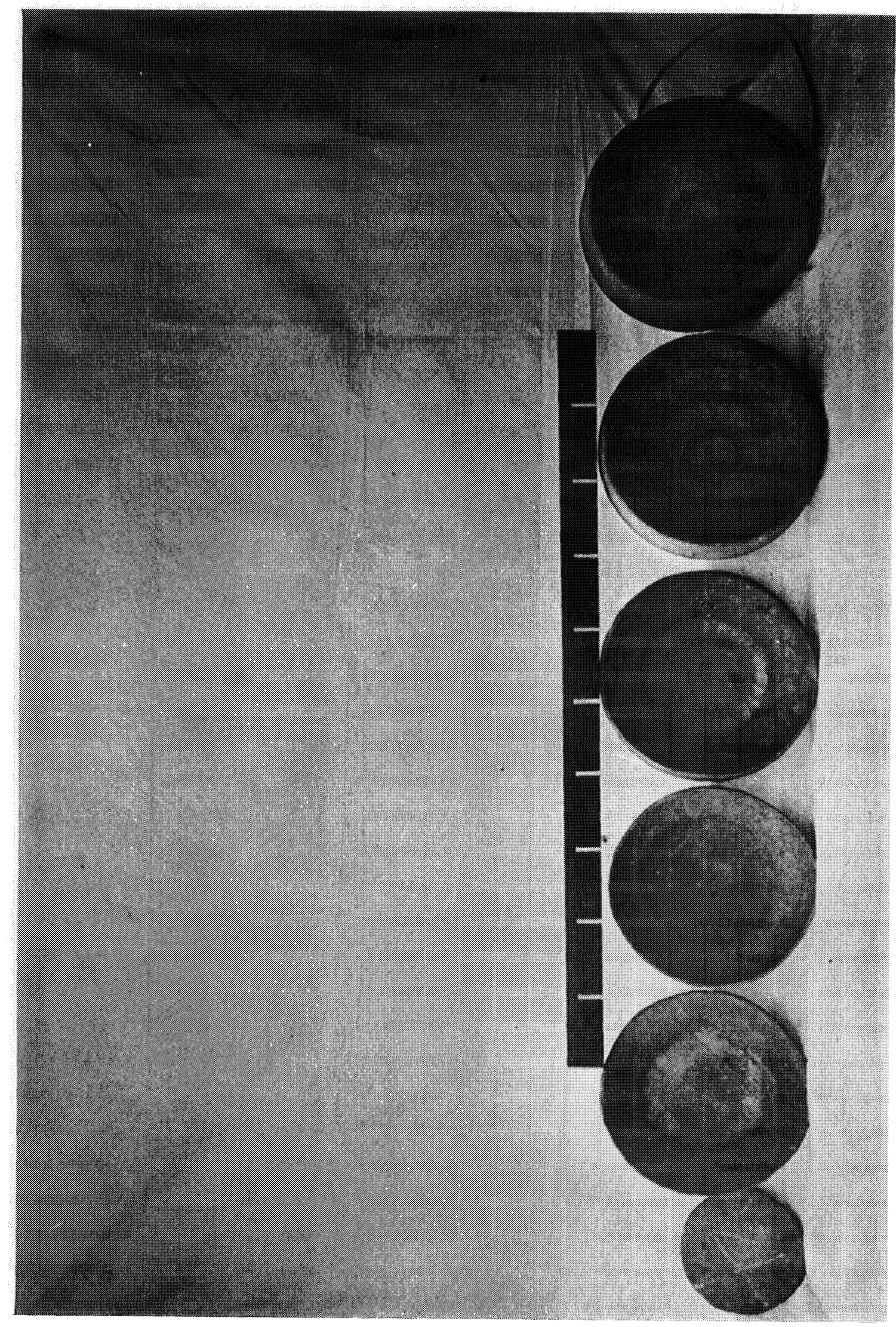

Plate X 


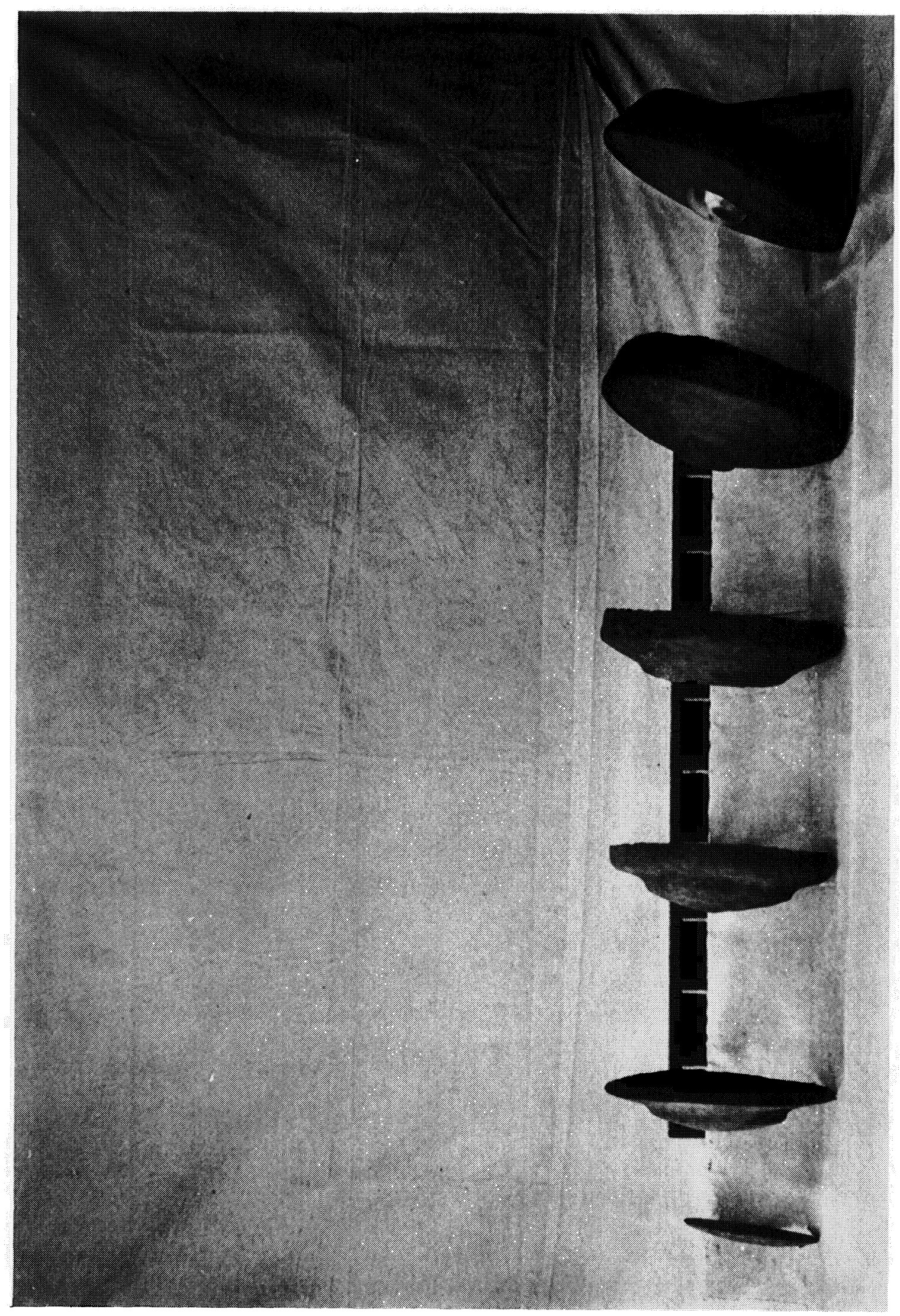

Plate XI 


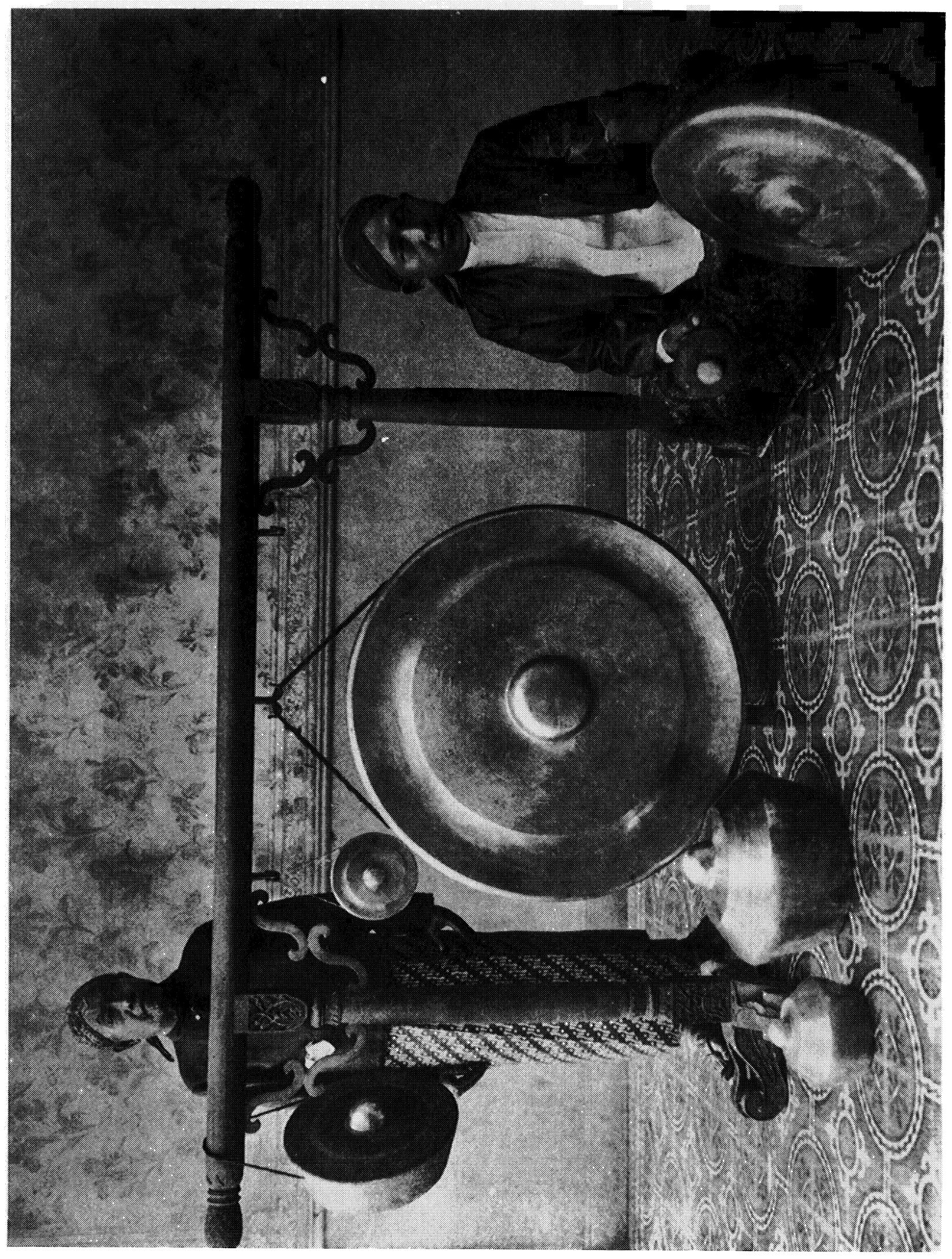




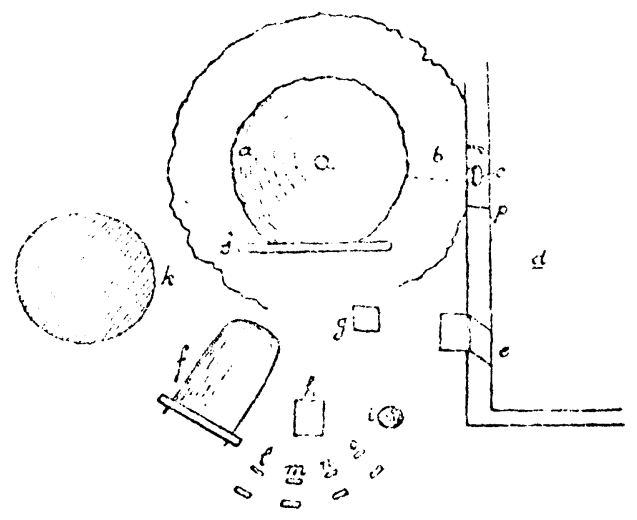

Figure 1

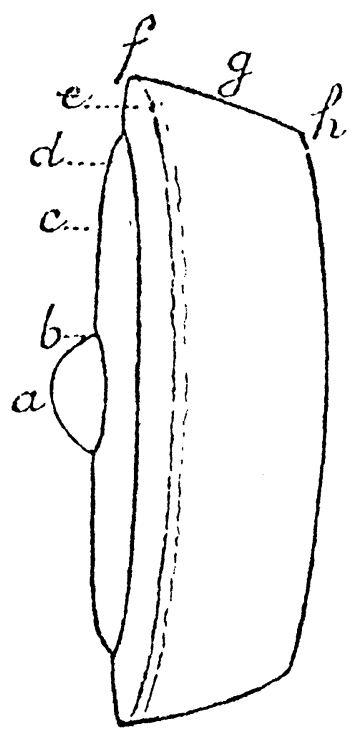

Figure 2

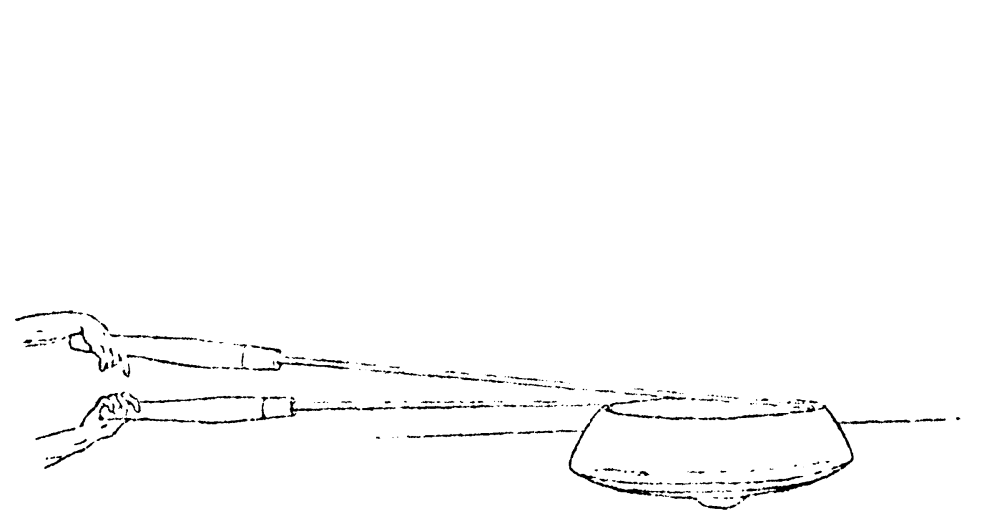

Figure 3

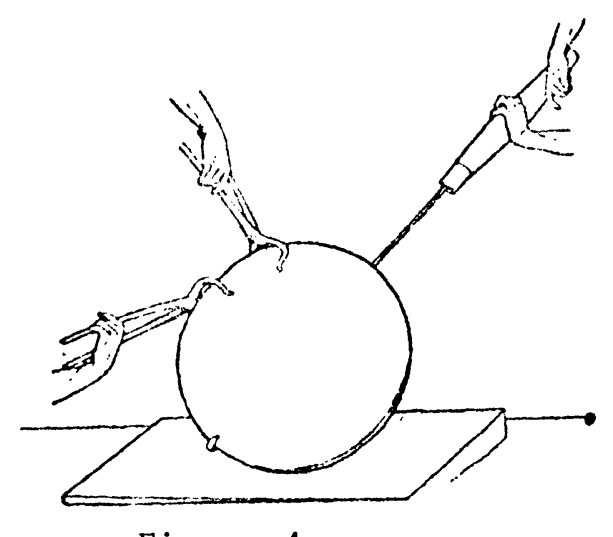

Figure 4

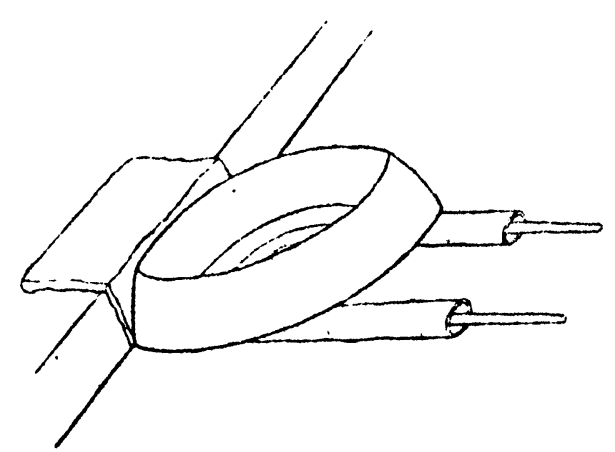

Figure 5

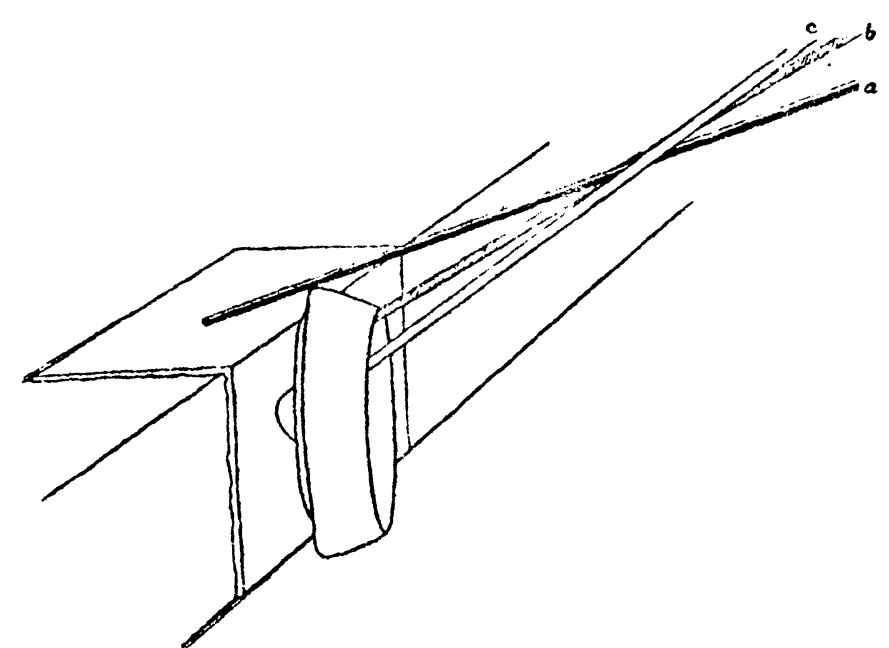

Figure 6 


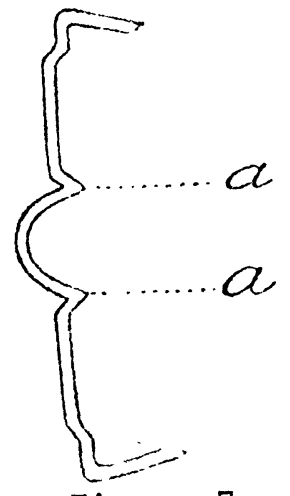

Figure 7

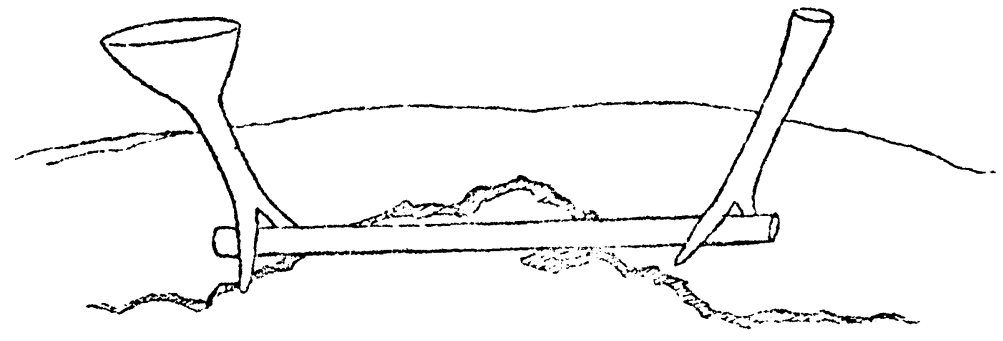

Figure 8

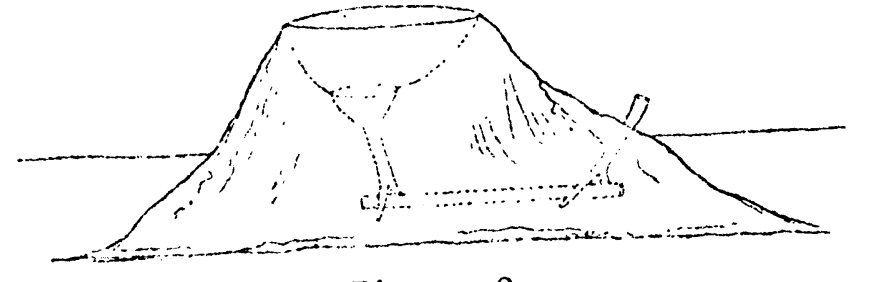

Figure 9

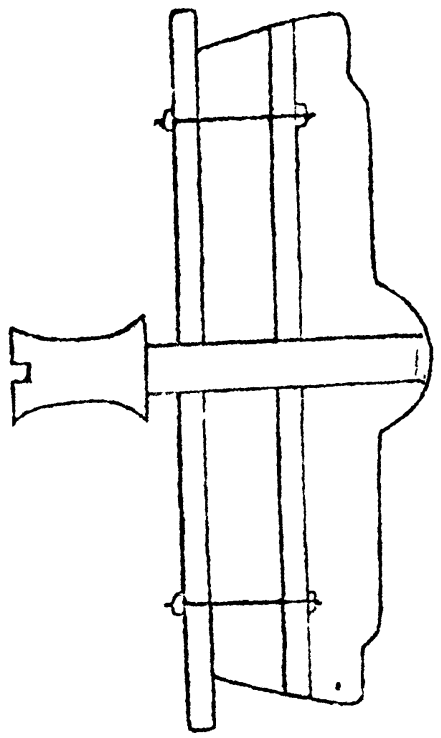

Figure 11

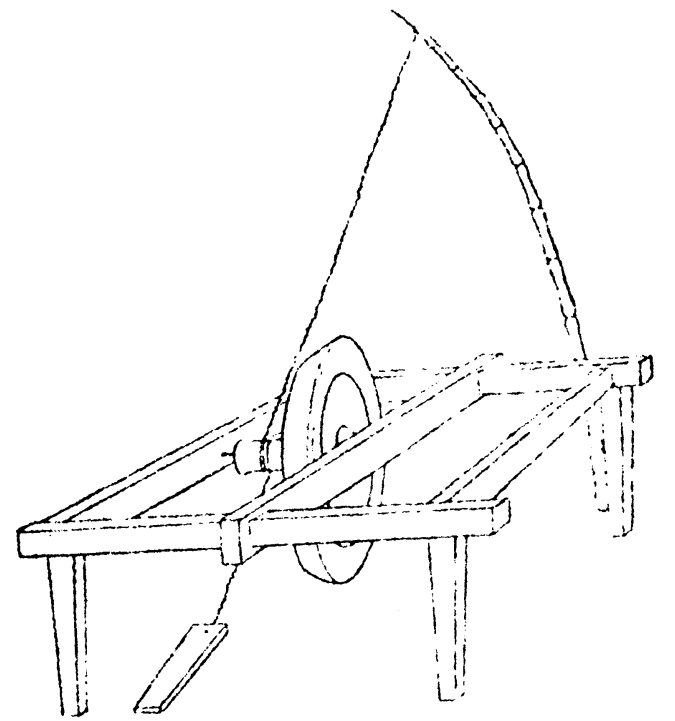

Figure 10

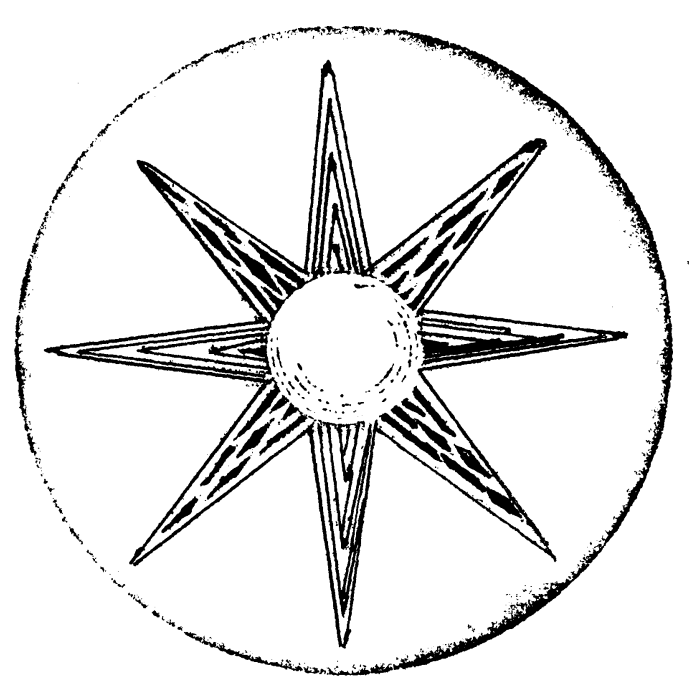

Figure 12 
LIST OF JAVANESE TERMS, IN LATIN AND JAVANESE SCRIPTS

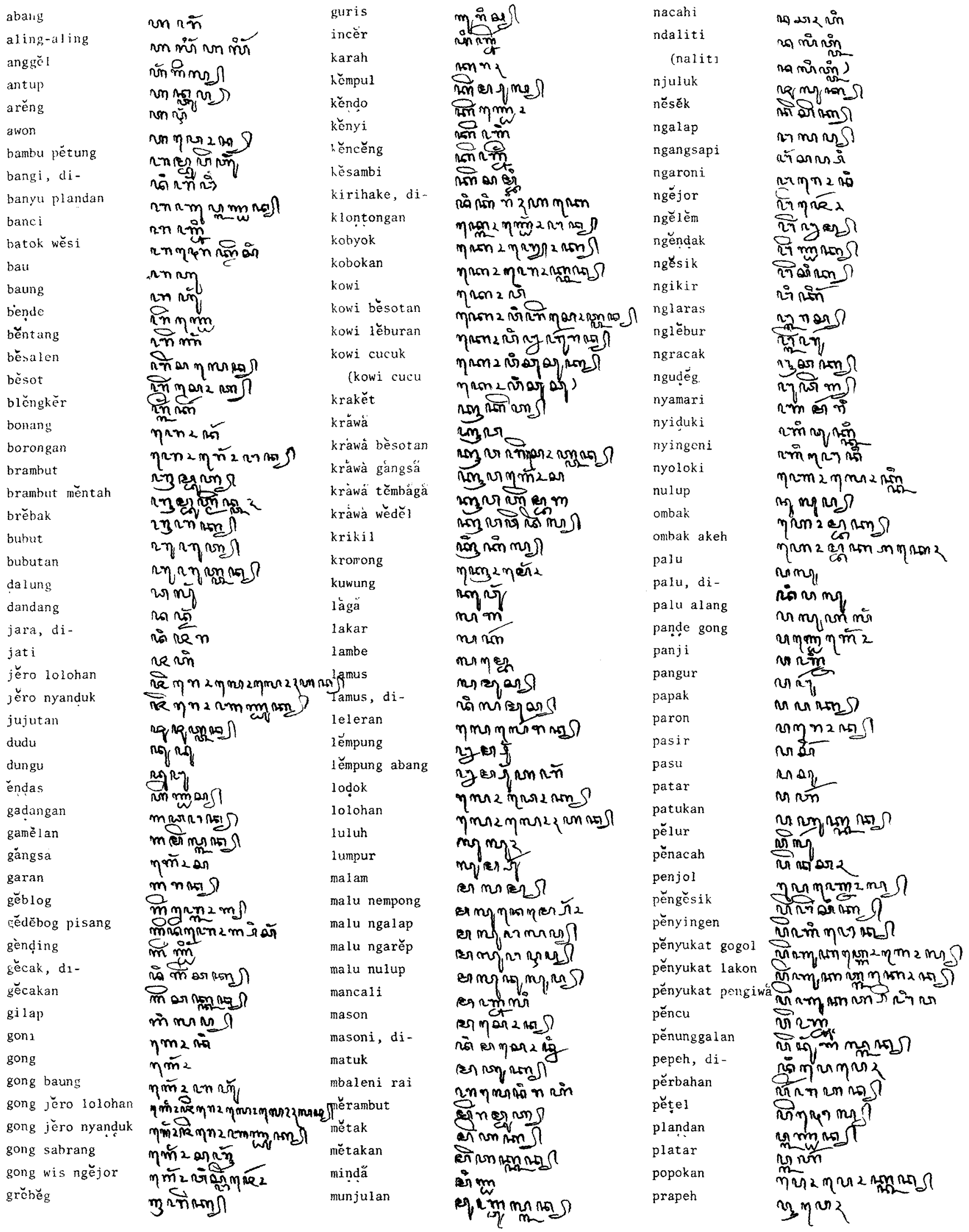




\begin{tabular}{|c|c|c|c|c|c|}
\hline $\begin{array}{l}\text { prapen } \\
\text { punuk } \\
\text { rai } \\
\text { réjĕb } \\
\text { rewang } \\
\text { sĕlĕt } \\
\text { sok, di- } \\
\text { sudà } \\
\text { suling } \\
\text { supit } \\
\text { suwĕl } \\
\text { swàră } \\
\text { swàrá akeh } \\
\text { swàrä siji } \\
\text { tabuh } \\
\text { tanjak } \\
\text { tawak } \\
\text { télale } \\
\text { tëlundak } \\
\text { tĕlutuh lo }\end{array}$ & 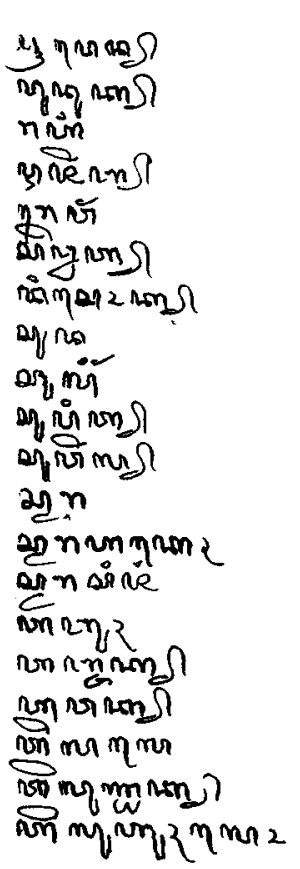 & $\begin{array}{l}\text { tĕmbágà } \\
\text { tĕmbàgà bolu } \\
\text { těmbàgă lantakan } \\
\text { těmbägä rosokan } \\
\text { těmbăgà sagu } \\
\text { tikēl } \\
\text { timah rĕjàsá } \\
\text { canang } \\
\text { canang nägä } \\
\text { congklok } \\
\text { conțong } \\
\text { cocor mindan } \\
\text { cocor sélĕtan } \\
\text { cucuk } \\
\text { tukang gĕnding } \\
\text { tukang gilap } \\
\text { tukang kikir } \\
\text { tukang kowi } \\
\text { tunggak }\end{array}$ & 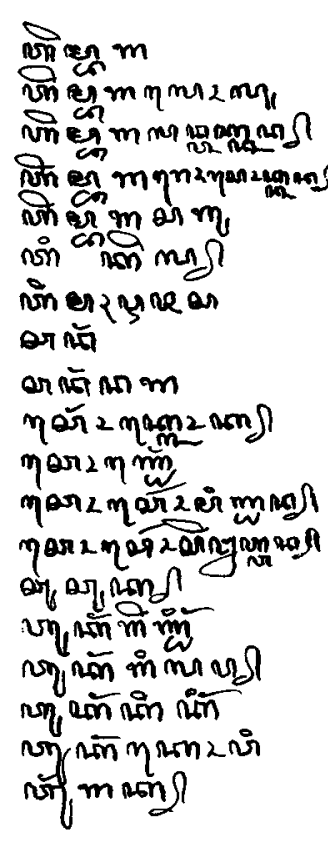 & 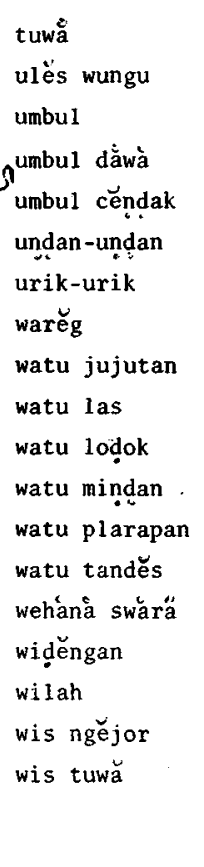 & 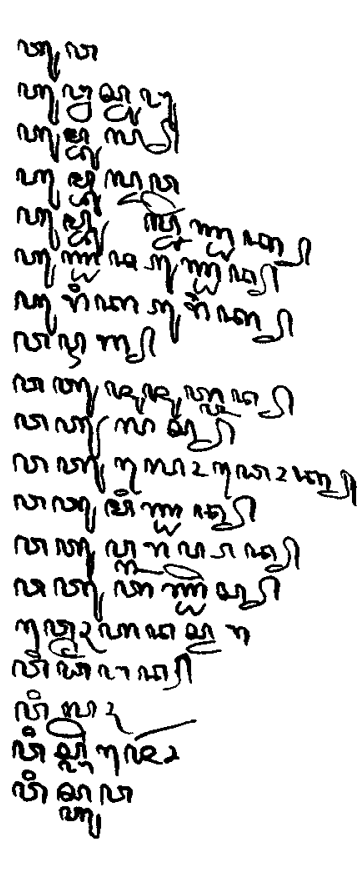 \\
\hline
\end{tabular}

PRONUNCIATION GUIDE

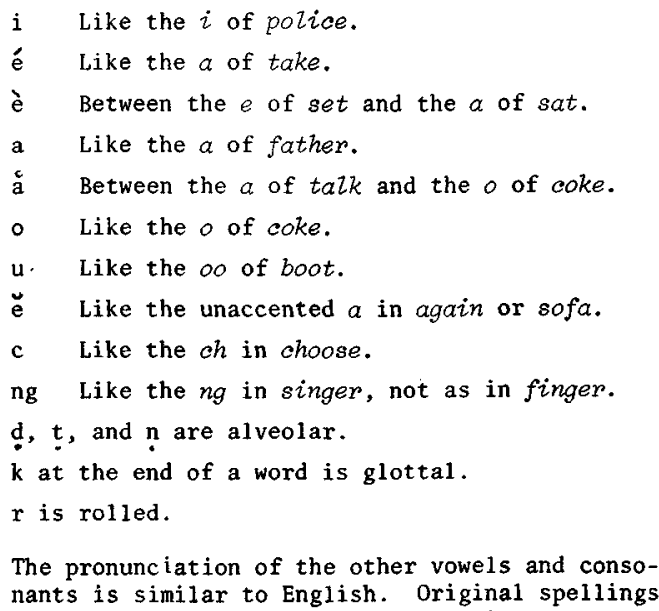

nants is similar to English. Original spellings

are preserved in bibliographic entries. 